Article

\title{
The Compressive Strength and Microstructure of Alkali-Activated Binary Cements Developed by Combining Ceramic Sanitaryware with Fly Ash or Blast Furnace Slag
}

\author{
Juan Cosa ${ }^{1}$ (i) , Lourdes Soriano $^{1}$, María Victoria Borrachero ${ }^{1}$, Lucía Reig ${ }^{2}{ }^{(\mathbb{D})}$, Jordi Payá ${ }^{1}{ }^{(0)}$ and \\ José María Monzó 1,* (iD) \\ 1 ICITECH-Instituto de Ciencia y Tecnología del Hormigón, Grupo de Investigación en Química de los \\ Materiales (GIQUIMA), Universitat Politècnica de València, 46022 Valencia, Spain; juacoma2@upv.es (J.C.); \\ lousomar@upvnet.upv.es (L.S.); vborrachero@cst.upv.es (M.V.B.); jjpaya@cst.upv.es (J.P.) \\ 2 EMC-Department of Mechanical Engineering and Construction, Universitat Jaume I, \\ 12071 Castellón de la Plana, Spain; lreig@uji.es \\ * Correspondence: jmmonzo@cst.upv.es; Tel.: +34-963-877-564
}

Received: 25 May 2018; Accepted: 2 August 2018; Published: 5 August 2018 updates

\begin{abstract}
The properties of a binder developed by the alkali-activation of a single waste material can improve when it is blended with different industrial by-products. This research aimed to investigate the influence of blast furnace slag (BFS) and fly ash (FA) (0-50 wt \%) on the microstructure and compressive strength of alkali-activated ceramic sanitaryware (CSW). $4 \mathrm{wt} \% \mathrm{Ca}(\mathrm{OH})_{2}$ was added to the CSW/FA blended samples and, given the high calcium content of BFS, the influence of BFS was analyzed with and without adding $\mathrm{Ca}(\mathrm{OH})_{2}$. Mortars were used to assess the compressive strength of the blended cements, and their microstructure was investigated in pastes by X-ray diffraction, thermogravimetry, and field emission scanning electron microscopy. All the samples were cured at $20^{\circ} \mathrm{C}$ for 28 and 90 days and at $65^{\circ} \mathrm{C}$ for 7 days. The results show that the partial replacement of CSW with BFS or FA allowed CSW to be activated at $20^{\circ} \mathrm{C}$. The CSW/BFS systems exhibited better mechanical properties than the CSW/FA blended mortars, so that maximum strength values of 54.3 MPa and 29.4 MPa were obtained in the samples prepared with $50 \mathrm{wt} \% \mathrm{BFS}$ and FA, respectively, cured at $20^{\circ} \mathrm{C}$ for 90 days.
\end{abstract}

Keywords: sustainable construction materials; waste management; alkali-activated binder; fly ash; blast furnace slag; ceramic sanitaryware; mechanical strength; microstructure

\section{Introduction}

Portland cement is the most commonly used synthetic construction material. Although its properties and behavior are well-known, the greenhouse gases emitted during its production, together with the natural resources used, have motivated new more eco-efficient binders, such as alkali-activated cements, to be developed. As explained by Zedan et al. [1], alkali-activated binders may be classified into two main types: low-calcium systems, which generally require applying temperature to set; and calcium-based binders, which usually harden at room temperature. While N-A-S-H gel mainly forms in the former, the activation of high-calcium systems principally brings about $\mathrm{C}-\mathrm{A}-\mathrm{S}-\mathrm{H}$ gel $[2,3]$. Both gels may co-exist in the presence of calcium, with calcium silicate hydrate $(\mathrm{C}-\mathrm{A}-\mathrm{S}-\mathrm{H})$ being favored at a high $\mathrm{pH}(>12)$ if sufficient calcium is provided [4].

Alkali-activated fly ash (FA) and blast furnace slag (BFS) may be considered the models for lowand high-calcium binders, respectively [3]. FA is obtained by the electro-static separation of dust from 
fuel gases in coal thermoelectric plants [5] and, according to [6,7], it is estimated that approximately 750-780 million tons are produced yearly. Granulated BFS is formed by rapidly cooling melted slag during iron production [8]. As reported by the World Steel Association [9], 1629.6 million tons of steel were produced worldwide in 2016, of which $74.3 \%$ are made in blast furnaces and the remaining $25.7 \%$ in electric furnaces. Consequently, approximately 300-360 million tons of iron slag were produced globally in blast furnaces in 2016, and 160-240 million tons of steel slag were generated in electric arc and basic oxygen furnaces [10].

In the last few decades, the use of different silico aluminate waste materials as a precursor in alkali-activated binders has been widely investigated [11,12]. Reusing waste materials as a precursor positively contributes to sustainable development because it limits the mining of natural resources, reduces the visual impact caused by accumulated waste, and diminishes the emissions associated with Portland cement manufacture $[13,14]$. Ceramic materials are a very interesting option to be explored to develop alkali-activated cements as they are chemically inert and present a long biodegradation period (up to 4000 years) [15]. Among them, ceramic sanitaryware waste (CSW) units are expected to present quite a homogeneous chemical and mineralogical composition since they are generally sintered within a narrow range of calcination temperatures (1200-1280 ${ }^{\circ} \mathrm{C}$ [16]). Moreover, CSW units (i.e., washbasins, lavatories, or bidets) can be easily separated from construction and demolition waste (CDW), which implies that they will present fewer impurities, such as gypsum or Portland cement. As reported by Baraldi [17], nearly 349.3 million CSW units were globally produced in 2014, of which almost $12 \%$ (41.6 million) was manufactured in the European Union.

CSW was successfully activated in a previous study by Reig et al. [18], where maximum strength values of $36 \mathrm{MPa}$ were obtained in mortars cured at $65^{\circ} \mathrm{C}$ for 7 days. However, addition of $\mathrm{Ca}(\mathrm{OH})_{2}$ and applying temperature to cure samples proved essential to successfully activate this ceramic waste material, which limited its use mainly to prefabricated applications. In order to improve the properties of alkali-activated binders developed using a single material as a precursor, several studies have lately combined low-calcium precursors, like CSW, with different sources of calcium and reactive $\mathrm{Al}_{2} \mathrm{O}_{3}$, such as BFS [1,2,19-23], FA [6], calcium aluminate cement (CAC) or Portland cement (PC) [24,25]. Robayo-Salazar et al. [19] observed that the heat of reaction in an alkali-activated natural pozzolan/BFS binary cement increased with BFS addition, which accelerated the kinetics of the process and, consequently, favored the activation of the pozzolan at room temperature, as well as strength development. A very positive influence of $\mathrm{PC}, \mathrm{CAC}$, and $\mathrm{Ca}(\mathrm{OH})_{2}$ on the microstructure and mechanical properties of alkali-activated CSW is reported in [24], where compressive strength values of $40.06 \mathrm{MPa}, 64.41 \mathrm{MPa}$, and $56.62 \mathrm{MPa}$ are reported in mortars containing $6 \mathrm{wt} \% \mathrm{Ca}(\mathrm{OH})_{2}, 10 \mathrm{wt} \%$ $\mathrm{PC}$ and $10 \mathrm{wt} \% \mathrm{CAC}$, respectively (all cured at $65{ }^{\circ} \mathrm{C}$ for 7 days). However, the natural resources used, and the large amounts of $\mathrm{CO}_{2}$ emitted to the atmosphere during CAC or PC production, motivated a later study, which explored the influence of spent fluid catalytic cracking waste (an industrial by-product) on the microstructure and compressive strength of alkali-activated CSW [26]. FCC significantly improves the reactivity of CSW, and compressive strength values of $40 \mathrm{MPa}$ and 60.4 $\mathrm{MPa}$ have been reported in the mortars cured at $20^{\circ} \mathrm{C}$ for 28 days, blended with $30 \mathrm{wt} \%$ and $50 \mathrm{wt} \%$ FCC, respectively.

The present study aims to investigate the influence of BFS and FA (0-50 wt \% each), together with the addition of $\mathrm{Ca}(\mathrm{OH})_{2}$, on the compressive strength and microstructure of alkali-activated CSW.

\section{Experimental Process}

\subsection{Materials}

CSW units were supplied by the company Ideal Standard, located in Valencia (Spain). Units rejected due to production defects were broken with a hammer and crushed in a jaw crusher (BB200 by Retsch) to obtain particles smaller than $2 \mathrm{~mm}$. Crushed particles were formed mainly by a dense ceramic body and generally contained part of the glaze that covered the CSW unit. 
These particles homogenized after their particle size was reduced when milled in a jars turner roller (Roller 1 by Gabrielli), for which 5-L volume cylindrical alumina jars were used. Each jar was filled with $1500 \mathrm{~g}$ of CSW and $6500 \mathrm{~g}$ of alumina balls to be rotated for $6 \mathrm{~h}$ at $190 \mathrm{rpm}$ for the first $10 \mathrm{~min}$ and at $140 \mathrm{rpm}$ for the remaining time.

FA was supplied by Balalva S.L. (Onda, Spain), and was produced in the thermoelectric power plant in Escucha (Teruel, Spain). Particles were milled in an industrial mill for $10 \mathrm{~h}$, which were used as received. BFS was supplied by the cement company Cementval S.L. (Sagunto, Spain). This waste was dry-milled in a laboratory for $30 \mathrm{~min}$ using porcelain jars filled with $450 \mathrm{~g}$ of BFS and 98 alumina balls.

Sodium hydroxide pellets (98\% purity, supplied by Panreac), water and waterglass (supplied by Merck, with the following composition: $64 \% \mathrm{H}_{2} \mathrm{O}, 28 \% \mathrm{SiO}_{2}$, and $8 \% \mathrm{Na}_{2} \mathrm{O}$ ) were used to prepare the activating solutions. $4 \mathrm{wt} \% \mathrm{Ca}(\mathrm{OH})_{2}(95 \%$ purity) was used as an addition to the $100 \mathrm{wt} \% \mathrm{CSW}$ and some blended samples (specified in the next section).

\subsection{Experimental Process and Tests Performed}

Before using the CSW, FA and BFS waste materials as precursors to develop alkali-activated binary cements, they were characterized to determine the morphology, particle size distribution (PSD), amorphous content, and the chemical and mineralogical composition of the milled powders. The shape of particles was observed by field emission scanning electron microscopy in an FESEM ULTRA 55 (ZEISS, Oberkochen, Germany). Powders were carbon-coated prior to their observation, and images were taken at $2 \mathrm{kV}$. PSD was determined by laser diffraction in a Mastersizer 2000 (Malvern Instruments, Malvern, UK). Powder was dispersed in water and stirred at $1200 \mathrm{rpm}$ and, in order to disperse possible powder agglomerations, a 1-min ultrasound was applied. The amorphous contents of CSW, FA, and BFS were determined following Standard UNE EN 196-2:2006, and their chemical composition was assessed by X-ray fluorescence (XRF) in a Magix Pro spectrometer (Philips, Netherland). Powder X-ray diffraction (XRD) analyses were performed in a Brucker AXS D8 Advance (Billerica, MA, USA), from 10 to $702 \theta$ degrees. $\mathrm{Cu} \mathrm{K} \alpha$ radiation at $20 \mathrm{~mA}$ and $40 \mathrm{kV}$ was used, with a 2-s accumulation time in a 0.02-angle step.

Three different systems were designed to investigate the influence of BFS and FA, together with the addition of $\mathrm{Ca}(\mathrm{OH})_{2}$, on the alkali-activation of CSW:

- System 1: 0 to $50 \mathrm{wt} \%$ CSW was replaced with BFS, a high-calcium waste material. A $100 \mathrm{wt} \%$ BFS sample was also prepared for comparison purposes, and no $\mathrm{Ca}(\mathrm{OH})_{2}$ was added to this system.

- $\quad$ System 2: 0 to 50 wt \% CSW was replaced with a low-calcium FA. 4 wt \% Ca(OH) 2 (amount determined according to the previous results reported in $[18,27]$ ) was added to these CSW blended pastes and mortars. A $100 \mathrm{wt} \%$ FA sample was also prepared as a reference (no $\mathrm{Ca}(\mathrm{OH})_{2}$ was added to this sample).

- System 3: 0 to 50 wt \% CSW was replaced with BFS and 4 wt $\% \mathrm{Ca}(\mathrm{OH})_{2}$ was added to these blended samples. The microstructure and mechanical properties of this system were compared with those observed in the alkali-activated CSW/BFS with no added $\mathrm{Ca}(\mathrm{OH})_{2}($ System 1$)$ and the alkali-activated CSW/FA binders (System 2).

Table 1 summarizes the three different developed systems, designation of samples, percentages of replacement of CSW with FA or BFS, and $\mathrm{Ca}(\mathrm{OH})_{2}$ addition. Samples were named according to the waste material and the CSW replacement percentage, and letter " $\mathrm{C}$ " denoted the addition of $4 \mathrm{wt} \%$ $\mathrm{Ca}(\mathrm{OH})_{2}$. Thus BFS/30, C-FA/50 and C-BFS/40 corresponded to the CSW samples blended with $30 \mathrm{wt} \% \mathrm{BFS}, 50 \mathrm{wt} \% \mathrm{FA}$ with $4 \mathrm{wt} \% \mathrm{Ca}(\mathrm{OH})_{2}$, and $40 \mathrm{wt} \% \mathrm{BFS}$ with $4 \mathrm{wt} \% \mathrm{Ca}(\mathrm{OH})_{2}$, respectively. 
Table 1. Designation of samples, ceramic sanitaryware (CSW) replacement with blast furnace slag (BFS), or fly ash (FA), and samples with $\mathrm{Ca}(\mathrm{OH})_{2}$ addition.

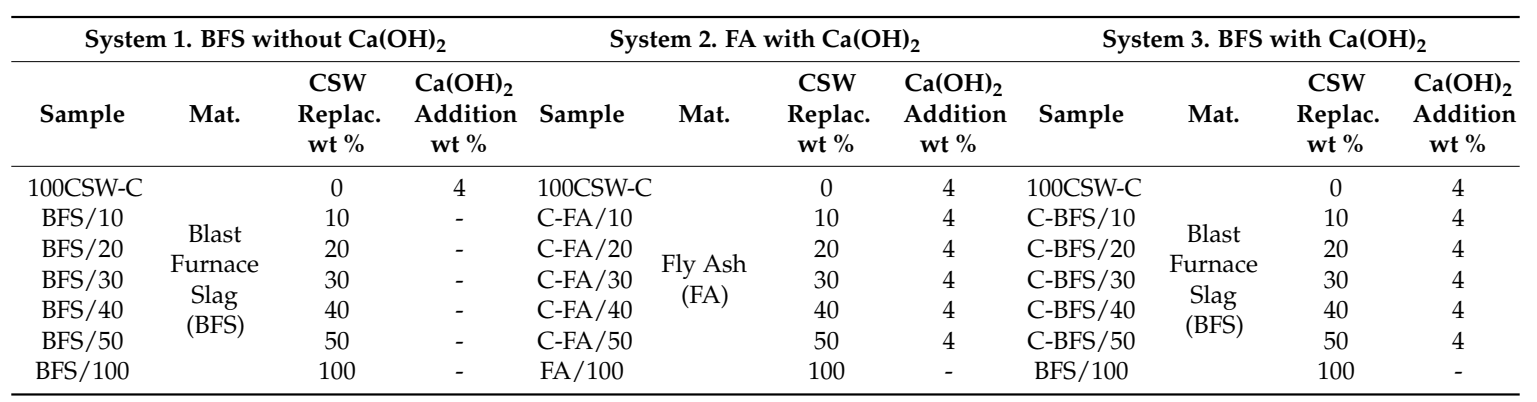

The compressive strength $\left(\sigma_{\mathrm{c}}\right)$ of the blended systems was assessed in mortars according to Standard UNE EN 196-1, and pastes were used to investigate microstructural evolution, by XRD, FESEM, and thermogravimetric analyses (TG). The XRD and FESEM tests were run according to the experimental processes described at the beginning of this section, and the TG experiments were run in a Mettler Toledo TGA 850 thermobalance, from $35^{\circ} \mathrm{C}$ to $600{ }^{\circ} \mathrm{C}$, at a heating rate of $10^{\circ} \mathrm{C} \cdot \mathrm{min}^{-1}$. Tests were performed in a nitrogen atmosphere at a flow gas rate of $75 \mathrm{~mL} \cdot \mathrm{min}^{-1}$. To better distinguish the thermogravimetric events, aluminum-sealed crucibles $(100-\mu \mathrm{L}$ volume) with a pinholed lid were used, which allowed a self-generated atmosphere to be created.

\subsection{Mix Proportions and Preparing Pastes and Mortars}

The mix proportions, the $\mathrm{SiO}_{2} / \mathrm{Na}_{2} \mathrm{O}$ molar ratio and the curing conditions used herein are summarized in Table 2. The concentrations of $\mathrm{Na}_{2} \mathrm{O}$ and $\mathrm{SiO}_{2}$ in the activating solution (defined in molality terms, moles per $\mathrm{kg}$ of water) were taken from previous studies on the alkali-activation of CSW [18], where the best compressive strength results (36 MPa after 7 curing days at $65{ }^{\circ} \mathrm{C}$ ) were achieved with the solutions containing 3.75 and $7.28 \mathrm{~mol} \cdot \mathrm{kg}^{-1}$ of $\mathrm{Na}_{2} \mathrm{O}$ and $\mathrm{SiO}_{2}$, respectively. A water/binder ratio of 0.45 was used to prepare all the samples. Water was provided by the sodium silicate solution and the binder was formed by CSW, and its partial replacement with FA or BFS (calcium hydroxide was used as an addition to the binder in the samples indicated in Table 1). Pastes and mortars were cured at $20^{\circ} \mathrm{C}$ at $95 \%$ relative humidity in a temperature- and humidity-controlled chamber, and at $65{ }^{\circ} \mathrm{C}$ in a thermostatically controlled bath inside a sealed box floating in water $(100 \% \mathrm{RH})$.

Table 2. The mix proportions, ratios and curing conditions used to assess the influence of BFS and FA on the alkali-activated CSW blended systems.

\begin{tabular}{|c|c|c|c|c|c|c|}
\hline$w / b^{(a)}$ & $\mathrm{Na}_{2} \mathrm{O} \mathrm{mol} \cdot \mathrm{kg}^{-1}$ & $\mathrm{SiO}_{2} \mathrm{~mol} \cdot \mathrm{kg}^{-1}$ & $\mathrm{SiO}_{2} / \mathrm{Na}_{2} \mathrm{O}$ & $\mathrm{Na}_{2} \mathrm{O}$ mol $\cdot \mathrm{kg}_{\text {binder }}{ }^{-1}$ & $\mathrm{SiO}_{2} \mathrm{~mol} \cdot \mathrm{kg}_{\text {binder }}{ }^{-1}$ & Curing Conditions \\
\hline 0.45 & 3.75 & 7.28 & 1.94 & 1.69 & 3.28 & $\begin{array}{c}7 \text { days at } 65^{\circ} \mathrm{C} \\
28 \text { and } 90 \text { days } 20^{\circ} \mathrm{C}\end{array}$ \\
\hline
\end{tabular}

(a) Water (w), provided by the sodium silicate solution; binder (b) composed of CSW and the different replacements with BFS or FA.

$\mathrm{CSW}, \mathrm{Ca}(\mathrm{OH})_{2}$, and the corresponding amount of FA or BFS were mixed until a homogeneous blend was obtained. To prepare the alkali-activating solutions, $\mathrm{NaOH}$ pellets were dissolved in the required amount of waterglass. Solutions were cooled at room temperature before being used to prepare pastes and mortars. The mortar samples sized $40 \times 40 \times 160 \mathrm{~mm}^{3}$ were prepared using siliceous sand with a fineness modulus of 4.3 at a binder/sand ratio of 1:3. These prismatic samples were wrapped in plastic film until testing age to avoid loss of moisture and to prevent efflorescence formation. 


\subsection{Further Studies on the Influence of BFS and $\mathrm{Ca}(\mathrm{OH})_{2}$ in the Alkali-Activated CSW Blended Systems}

After analyzing the influence of BFS, FA, and $\mathrm{Ca}(\mathrm{OH})_{2}$ on the compressive strength of the alkali-activated CSW blended mortars, further research was conducted to better understand the role of $\mathrm{BFS}$ and $\mathrm{Ca}(\mathrm{OH})_{2}$ in the CSW / BFS systems. The following new mortars were prepared:

- $\quad$ a $100 \mathrm{wt} \%$ BFS mortar with a higher $\mathrm{Na}_{2} \mathrm{O}$ concentration $\left(7.5 \mathrm{~mol} \cdot \mathrm{kg}^{-1}\right.$ instead of $\left.3.75 \mathrm{~mol} \cdot \mathrm{kg}^{-1}\right)$;

- $\quad 50 \mathrm{wt} \%$ BFS mortars blended with two different high-crystallinity materials: kephalite (and alucite, silicoaluminate in nature) and sikron (flour quartz, siliceous in nature). Both were prepared without $\mathrm{Ca}(\mathrm{OH})_{2}$ and with the addition of $4 \mathrm{wt} \%$;

- $\quad 50 \mathrm{wt} \%$ XXX/BFS mortars (where XXX: CSW or kephalite), with 0,4 and $8 \mathrm{wt} \% \mathrm{Ca}(\mathrm{OH})_{2}$;

- a $100 \mathrm{wt} \%$ kephalite with the addition of $4 \mathrm{wt} \% \mathrm{Ca}(\mathrm{OH})_{2}$.

All these mortars (except the new $100 \mathrm{wt} \%$ BFS) were prepared using the mix proportions summarized in Table 2. As the objective of these additional tests was to acquire additional data to help corroborate some hypotheses, these mortars were cured only at $65^{\circ} \mathrm{C}$ for 7 days (the curing condition that generally provided the best compressive strength results).

\section{Results}

\subsection{Characteristics of the Waste Materials}

Figure 1 shows the granulometric distribution of the milled powders, whose main parameters are summarized in Table 3 (the $d_{10}, d_{50}$ and $d_{90}$ values represent the percentages in volume of particles below the indicated diameter). All the materials had a mean diameter under $32 \mu \mathrm{m}, 90 \mathrm{vol} \%$ under $75 \mu \mathrm{m}$ and $10 \mathrm{vol} \%$ under $3 \mu \mathrm{m}$. CSW and BFS showed similar granulometric distributions, where the CSW particles were slightly larger than BFS, and FA was the finest powder used. As observed by Temuujin et al. [28], a reduction in particle size may increase the dissolution rate of particles, facilitating the binder setting and leading to improved compressive strength results.

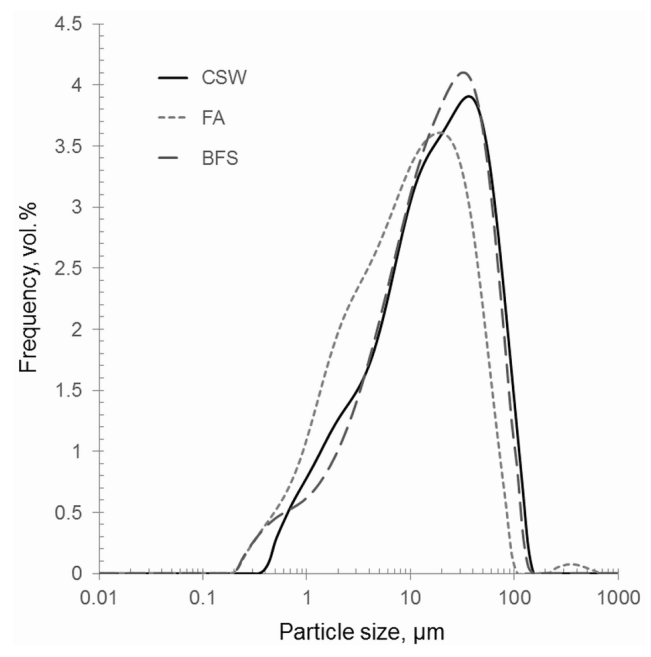

Figure 1. Granulometric distribution of the milled CSW, BFS, and FA particles.

Table 3. Main granulometric parameters of the milled waste materials.

\begin{tabular}{ccccc}
\hline Waste Materials & $\mathbf{d}_{\mathbf{1 0}}, \boldsymbol{\mu m}$ & $\mathbf{d}_{\mathbf{5 0}}, \boldsymbol{\mu m}$ & $\mathbf{d}_{\mathbf{9 0}}, \boldsymbol{\mu m}$ & Mean Diameter, $\boldsymbol{\mu m}$ \\
\hline CSW & 2.92 & 22.38 & 73.32 & 31.24 \\
BFS & 2.78 & 20.60 & 66.16 & 28.54 \\
FA & 2.09 & 11.52 & 47.75 & 21.07 \\
\hline
\end{tabular}


The morphology of the milled CSW, BFS, and FA powders is presented in Figure 2. The CSW fragments were dense, irregular, and presented smooth surfaces. The BFS powder also had an irregular morphology, which was attributed to the decomposition of the slag while being rapidly cooled by a powerful flow of cold water, and to the milling conducted to reduce its particle size. The milled FA powder was composed of a combination of rounded and irregularly shaped FA particles. As explained by Ranjbar and Kuenzel [7], spherical particles enhance workability, as their smaller surface area reduces the water required to wet particles.
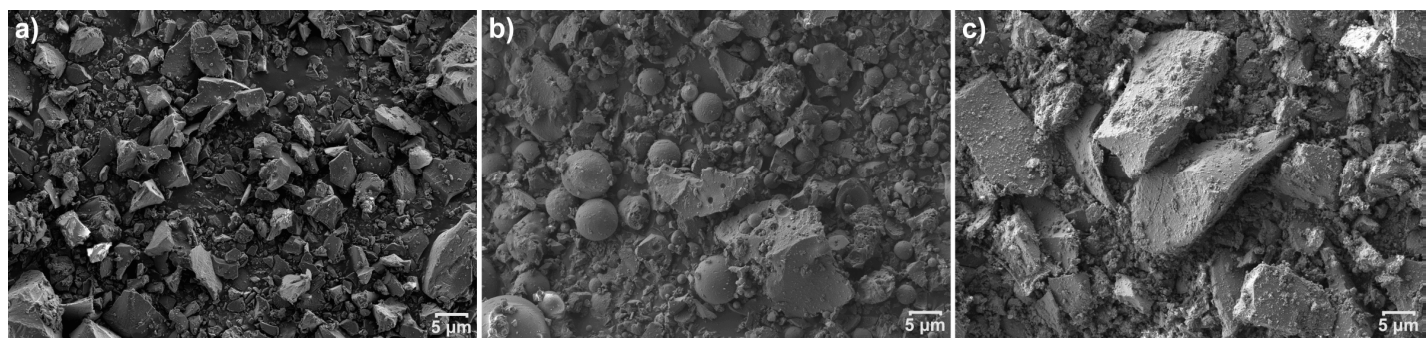

Figure 2. Images of the milled materials used as a precursor: (a) CSW; (b) FA; (c) BFS.

The XRD spectra of the CSW, BFS, and FA waste materials are shown in Figure 3. Quartz (Q, $\mathrm{SiO}_{2}$, Powder Diffraction File (PDF) \#331161) and mullite ( $\left.\mathrm{M}, \mathrm{Al}_{6} \mathrm{Si}_{2} \mathrm{O}_{13}, \mathrm{PDF} \# 150776\right)$ were the main crystalline compounds distinguished in CSW, along with small amounts of anorthite, a calcium feldspar (A, $\mathrm{CaAl}_{2} \mathrm{Si}_{2} \mathrm{O}_{8}, \mathrm{PDF} 4411486$ ). Crystalline quartz and mullite were also identified in FA, together with iron oxide maghemite $\left(\mathrm{F}, \mathrm{Fe}_{2} \mathrm{O}_{3} \mathrm{PDF} \# 251402\right)$ and traces of gypsum $\left(\mathrm{G}, \mathrm{CaSO}_{4} \cdot 2 \mathrm{H}_{2} \mathrm{O}\right.$ PDF\#330311). The spectra of both CSW and FA deviated from the baseline from 17 to $322 \theta$ degrees, which indicates the presence of some amorphous phases. BFS was essentially amorphous to XRD (halo located within the range of 23-37 $2 \theta$ degrees) and presented peaks that were attributed to the crystalline phases quartz and calcite $\left(\mathrm{C}, \mathrm{CaCO}_{3}, \mathrm{PDF} \# 050586\right)$. As observed by Ismail et al. [29], the different location of the amorphous hump of BFS compared with that of FA or CSW denotes structural differences in the amorphous phases of the waste materials.

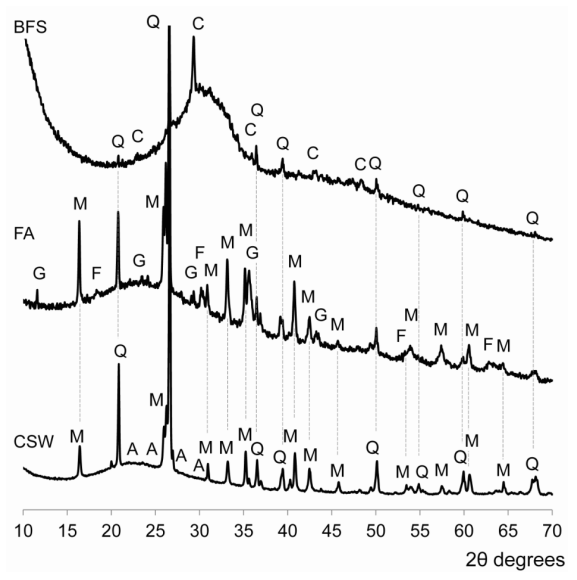

Figure 3. Mineralogical composition of the CSW, BFS, and FA raw materials. Quartz $\left(\mathrm{Q}, \mathrm{SiO}_{2}\right)$; Mullite ( $\left.\mathrm{M}, \mathrm{Al}_{6} \mathrm{Si}_{2} \mathrm{O}_{13}\right)$; Anorthite $\left(\mathrm{A}, \mathrm{CaAl}_{2} \mathrm{Si}_{2} \mathrm{O}_{8}\right)$; Calcite $\left(\mathrm{C}, \mathrm{CaCO}_{3}\right)$; Gypsum $\left(\mathrm{G}, \mathrm{CaSO}_{4} \cdot 2 \mathrm{H}_{2} \mathrm{O}\right)$; Maghemite $\left(\mathrm{F}_{1} \mathrm{Fe}_{2} \mathrm{O}_{3}\right)$.

Table 4 provides the chemical composition and amorphous content of the CSW, BFS, and FA waste materials used as precursors. CSW and FA exhibited high $\mathrm{SiO}_{2}$ and $\mathrm{Al}_{2} \mathrm{O}_{3}$ contents $(89.06$ and $75.71 \mathrm{wt} \%$, the sum of CSW and FA, respectively), which were significantly lower in BFS (40.64 wt \%). FA was classified as class F according to the ASTM C 618-08a specifications as it presented a $\mathrm{CaO}$ 
content below $15 \mathrm{wt} \%$. Conversely, the $40.35 \mathrm{wt} \% \mathrm{CaO}$ present in BFS motivated us to investigate the influence of $\mathrm{Ca}(\mathrm{OH})_{2}$ additions when replacing CSW with BFS (Systems 1 and 3, without and with $\mathrm{Ca}(\mathrm{OH})_{2}$, respectively). In line with the XRD results reported in Figure 3, 98.6 wt \% of BFS was in an amorphous state, while the production process of the CSW units gave the highest amount of crystalline stable phases.

Table 4. Chemical composition and amorphous content of CSW, BFS, and FA (wt \%).

\begin{tabular}{cccccccccccc}
\hline Waste Materials & $\mathrm{Al}_{\mathbf{2}} \mathbf{O}_{\mathbf{3}}$ & $\mathbf{S i O}_{2}$ & $\mathbf{C a O}$ & $\mathrm{Fe}_{2} \mathbf{O}_{3}$ & $\mathbf{K}_{\mathbf{2}} \mathbf{O}$ & $\mathbf{M g O}$ & $\mathbf{N a}_{\mathbf{2}} \mathbf{O}$ & $\mathbf{S O}_{3}$ & Other & $\mathbf{L O I}^{\mathbf{1}}$ & Amorph. Content \\
\hline $\mathrm{CSW}$ & 23.60 & 66.00 & 1.20 & 1.30 & 2.80 & 0.70 & 2.40 & 0.10 & 1.80 & 0.20 & 45.6 \\
FA & 25.80 & 49.91 & 3.84 & 13.94 & 2.47 & 1.06 & - & 1.00 & 0.01 & 1.97 & 71.4 \\
$\mathrm{BFS}$ & 10.60 & 30.04 & 40.35 & 1.30 & 0.57 & 7.47 & 0.87 & 1.94 & 1.30 & 5.56 & 98.6 \\
\hline
\end{tabular}

${ }^{1}$ Determined at $950{ }^{\circ} \mathrm{C}$.

\subsection{Compressive Strength}

Figure 4 summarizes the compressive strength results of the alkali-activated CSW/BFS and $\mathrm{CSW} / \mathrm{FA}$ blended mortars cured at $65^{\circ} \mathrm{C}$ for 7 days, and at $20^{\circ} \mathrm{C}$ for 28 and 90 days. The $100 \mathrm{wt} \%$ FA mortars and those prepared with 10 wt \% BFS without $\mathrm{Ca}(\mathrm{OH})_{2}$, were ruled out because they had not hardened after 2 curing days at $20^{\circ} \mathrm{C}$. Authors like Temuujin et al. [28] have successfully activated FA at room temperature, and achieved up to $45 \mathrm{MPa}$ after the mechanical activation of the ash. The differences with the $100 \mathrm{wt} \%$ FA mortars developed herein, which did not harden at $20^{\circ} \mathrm{C}$, were attributed mainly to the mix proportions in the alkali-activating solution, which had been optimized for the CSW precursor, but were most probably not optimum for FA. Additionally, the FA mechanically activated by Temuujin et al. [28] most probably had a smaller particle size, which would improve its dissolution rate. Another factor that could have influenced the hardening of the $100 \mathrm{wt} \%$ FA mortars is the absence of calcium, which would have accelerated the reaction kinetics.

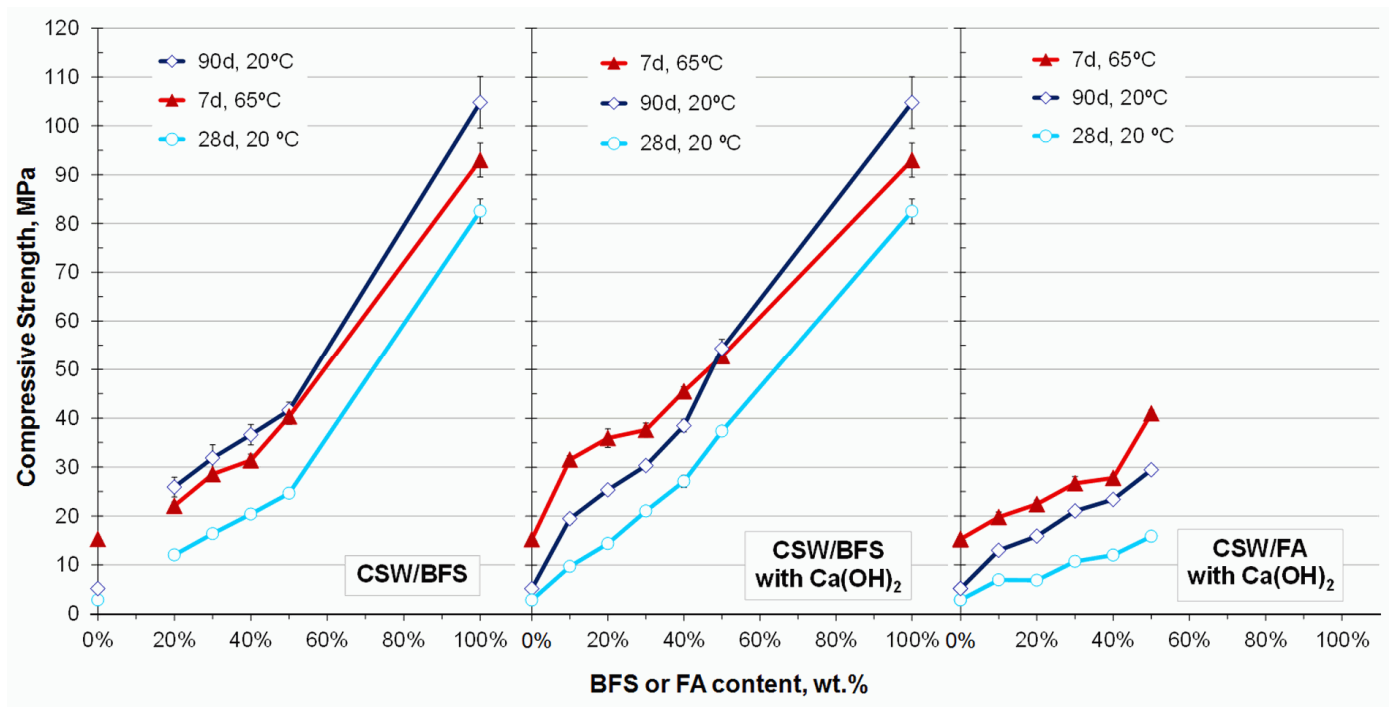

Figure 4. Evolution of compressive strength with the BFS and FA contents in the alkali-activated CSW mortars cured at $65{ }^{\circ} \mathrm{C}$ for 7 days and at $20^{\circ} \mathrm{C}$ for 28 and 90 days.

Addition of FA or BFS considerably improved the compressive strength of the alkali-activated CSW mortars, and allowed this ceramic waste to be activated at $20{ }^{\circ} \mathrm{C}$, which significantly extended its reuse possibilities as a precursor. A wide range of mechanical properties was obtained, depending on the replacement percentage of CSW with BFS or FA, and also on the curing conditions. For a given replacement percentage, improvement of strength became more significant in the CSW/BFS systems than in the CSW/FA ones. This was attributed to the high amorphous content and reactivity of BFS, 
which provided strength results over $80 \mathrm{MPa}$ after 28 curing days at $20^{\circ} \mathrm{C}(100 \mathrm{wt} \% \mathrm{BFS})$. Although the FA blended mortars cured at $20^{\circ} \mathrm{C}$ exhibited the poorest mechanical performance, the obtained strength results when cured at $65^{\circ} \mathrm{C}$ were similar to those provided by the BFS blended systems with no $\mathrm{Ca}(\mathrm{OH})_{2}$ addition. Unlike the BFS mortars, the CSW/FA systems showed a synergistic effect, since the $100 \mathrm{wt} \% \mathrm{FA}$ mortars did not set at $20^{\circ} \mathrm{C}$, and the strength of the $100 \mathrm{wt} \% \mathrm{CSW}$ mortars improved when partially replaced with FA. Provided that the calcium and $\mathrm{Al}_{2} \mathrm{O}_{3}$ contents in FA and CSW were similar (Table 4), the improved strength observed with increasing FA contents was attributed to the higher amorphous contents of FA.

The BFS blended mortars with no $\mathrm{Ca}(\mathrm{OH})_{2}$ addition had similar strength results after 7 curing days at $65^{\circ} \mathrm{C}$ or 90 days at $20^{\circ} \mathrm{C}$. The loss of strength of the CSW/BFS mortars (compared with the $100 \mathrm{wt} \%$ BFS mortar) generally came close to, or was even higher than, the CSW percentage in the system (except for the C-BFS mortars cured at $65^{\circ} \mathrm{C}$ ). By way of example, the strength of the mortars prepared with $30 \mathrm{wt} \%$ or $50 \mathrm{wt} \%$ BFS (without $\mathrm{Ca}(\mathrm{OH})_{2}$ ) diminished by approximately $70 \%$ and $60 \%$, respectively, after 7 curing days at $65{ }^{\circ} \mathrm{C}$ or 90 days at $20{ }^{\circ} \mathrm{C}$. Similarly, the C-BFS-blended mortars cured at $20^{\circ} \mathrm{C}$ for 90 days also exhibited strength loss values of $71.1 \%$ and $48.1 \%$ when prepared with $70 \mathrm{wt} \%$ and $50 \mathrm{wt} \% \mathrm{CSW}$, respectively. The addition of $\mathrm{Ca}(\mathrm{OH})_{2}$ is thought to accelerate the process kinetics since it improved the mechanical properties of the CSW/BFS mortars cured at $65{ }^{\circ} \mathrm{C}$ or at $20^{\circ} \mathrm{C}$ for 28 days, but hardly influenced those of the mortars cured for longer periods (similar strength values were obtained with and without $\mathrm{Ca}(\mathrm{OH})_{2}$ in the CSW / BFS mortars cured at $20^{\circ} \mathrm{C}$ for 90 days).

\subsubsection{Further Results on the Influence of BFS and $\mathrm{Ca}(\mathrm{OH})_{2}$ in the Alkali-Activated CSW Blended Systems}

As described in Section 3.2 above, the loss of strength observed in the CSW/BFS blended mortars, compared with the $100 \mathrm{wt} \%$ BFS reference sample, came close to the CSW content in the system. This suggests that CSW could act as an inert mineral addition when blended with BFS and, consequently, the activator would be consumed mainly by BFS, which would lead to excess sodium and silica for the diluted amount of BFS in the blended samples. $\mathrm{Ca}(\mathrm{OH})_{2}$ is also thought to accelerate the activation reactions in CSW/BFS systems, particularly those cured at $65^{\circ} \mathrm{C}$, or at $20^{\circ} \mathrm{C}$ for 28 days. Figure 5 shows the compressive strength results of the mortars prepared to corroborate these hypotheses. The strengths of the $100 \mathrm{wt} \% \mathrm{CSW}$ and $100 \mathrm{wt} \%$ BFS mortars, which are presented in Figure 4, are also included as references.

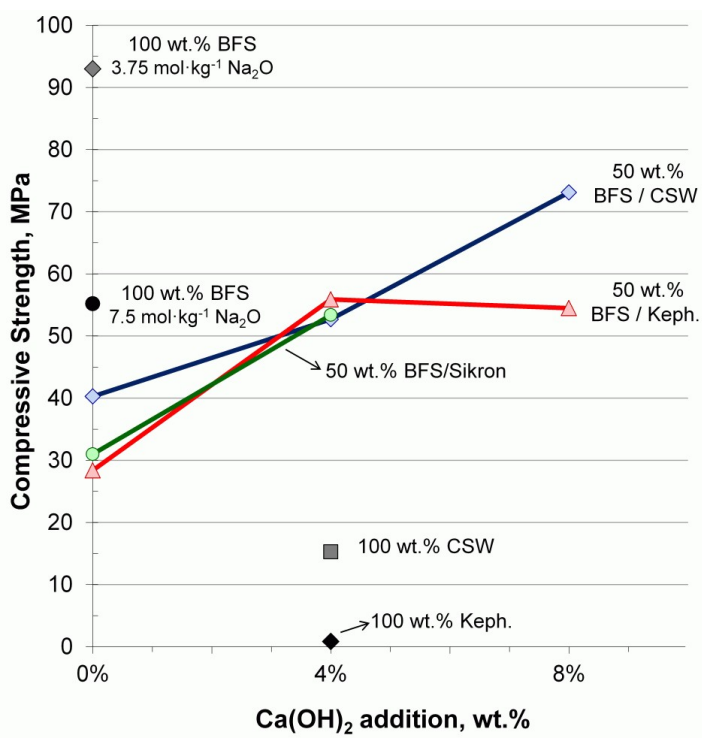

Figure 5. Compressive strength of the new mortars developed to further investigate the influence of $\mathrm{BFS}$ and $\mathrm{Ca}(\mathrm{OH})_{2}$ on alkali-activated CSW blended systems. 
The strength of the $100 \mathrm{wt} \%$ BFS mortar diminished from 93.0 MPa to 55.2 MPa when the sodium concentration was increased from $3.75 \mathrm{~mol} \cdot \mathrm{kg}^{-1}$ to $7.5 \mathrm{~mol} \cdot \mathrm{kg}^{-1}$. This suggests that, given the predominantly amorphous nature of BFS, this waste material consumed mainly the activating solution first, which led to excess sodium and silica for the amount of BFS in the blended system.

The 50 wt $\%$ BFS mortars prepared with 4 wt $\% \mathrm{Ca}(\mathrm{OH})_{2}$ exhibited similar compressive strength results, no matter what the material used to replace BFS (CSW, kephalite or sikron). However, when no $\mathrm{Ca}(\mathrm{OH})_{2}$ was added to the system, slightly better strength results were obtained in the $50 \mathrm{wt} \%$ BFS/CSW systems than in those blended with sikron or kephalite. Increasing the addition of $\mathrm{Ca}(\mathrm{OH})_{2}$ to $8 \mathrm{wt} \%$ favored the reactivity of the CSW/BFS mortars, which improved strength by $20.4 \mathrm{MPa}$, but did not affect that of the BFS/Kephalite sample. Additionally, $0.86 \mathrm{MPa}$ were given by the $100 \mathrm{wt} \%$ kephalite mortar, which were remarkably reduced compared with the $15.3 \mathrm{MPa}$ provided by the corresponding $100 \mathrm{wt} \% \mathrm{CSW}$ sample. All these results indicate some reactivity of the ceramic waste, which contributed to develop strength. Conversely, as suggested by Perná and Hanzlicek [20], although microstructural analyses would confirm the exact role of kephalite and sikron in the $50 \mathrm{wt} \%$ BFS blended mortars, these high crystallinity materials most probably acted as fillers, and were merely encapsulated in the binding matrix without creating any chemical bonds.

\subsection{X-ray Diffraction (XRD) Studies}

The XRD spectra for the CSW/BFS (with and without $\mathrm{Ca}(\mathrm{OH})_{2}$ ) and the CSW/FA blended pastes, cured at $20^{\circ} \mathrm{C}$ for 28 days and at $65^{\circ} \mathrm{C}$ for 7 days, are reported in Figures 6-8. The signals attributed to crystalline quartz $\left(\mathrm{Q}, \mathrm{SiO}_{2}, \mathrm{PDF} 3331161\right)$ and mullite $\left(\mathrm{M}, \mathrm{Al}_{6} \mathrm{Si}_{2} \mathrm{O}_{13}, \mathrm{PDF} \# 150776\right)$, which were previously identified in the raw CSW and FA materials, also arose in the diffractograms of the $100 \mathrm{wt} \%$ CSW, $100 \mathrm{wt} \% \mathrm{FA}$ and CSW/FA blended pastes. The peaks attributed to iron oxide maghemite (F, $\mathrm{Fe}_{2} \mathrm{O}_{3}$ PDF\#251402) were observed in the $100 \mathrm{wt} \%$ FA paste, and the signals due to anorthite (A, $\mathrm{CaAl}_{2} \mathrm{Si}_{2} \mathrm{O}_{8}, \mathrm{PDF} 4411486$ ), this being the calcium feldspar identified in the raw CSW waste, arose in the $100 \mathrm{wt} \% \mathrm{CSW}$ activated pastes and those containing $90 \mathrm{wt} \%$ CSW. Calcite, which was distinguished in the original BFS, was also identified in all the activated pastes containing this waste. This indicates that, given their stability, these crystalline phases scarcely participated in the activation reactions. Calcium silicate rankinite $\left(\mathrm{R}, \mathrm{Ca}_{3} \mathrm{Si}_{2} \mathrm{O}_{7}, \mathrm{PDF} \# 220539\right)$ emerged in the spectra of the $100 \mathrm{wt} \% \mathrm{BFS}$ pastes (with and without calcium addition), and small amounts of Natron $\left(\mathrm{N}, \mathrm{Na}_{2} \mathrm{CO}_{3} \cdot 10 \mathrm{H}_{2} \mathrm{O}, \mathrm{PDF} \# 150800\right)$ formed in the $100 \mathrm{wt} \% \mathrm{CSW}$ activated paste. This sodium carbonate has also been noted in previous works conducted into the alkali-activation of CSW [24,26], and has been attributed to the existence of non reacted reagents or to the carbonation of pastes. Although, as described by Marjanovic et al. [2], hydrotalcite gel usually forms in alkali-activated $100 \mathrm{wt} \%$ BFS when the original BFS contains more than $5 \% \mathrm{MgO}$ (the BFS used in our study had $7.47 \mathrm{wt} \% \mathrm{MgO}$; see Table 4) and is activated with sodium silicate solutions, no signals associated with this compound were clearly distinguished in any activated paste. The absence of hydrotalcite was attributed to the fact that small amounts formed, or it was poorly crystalline, which makes XRD identification difficult.

Addition of $4 \mathrm{wt} \% \mathrm{Ca}(\mathrm{OH})_{2}$ to the CSW/BFS system did not significantly modify the formed crystalline phases, and no major differences were observed between the crystalline compounds formed when cured at $20^{\circ} \mathrm{C}$ and at $65^{\circ} \mathrm{C}$ (in neither BFS nor the FA systems). No signals due to $\mathrm{Ca}(\mathrm{OH})_{2}$, which was added to the samples indicated in Table 1, were distinguished in the XRD patterns of the activated pastes. This finding indicates that calcium hydroxide was consumed during the activation process, and was incorporated into the newly-formed alkali-activated gel.

A deviation from the baseline toward higher $2 \theta$ values was observed in the activated pastes compared with the original materials, especially in the CSW/BFS blended pastes, which exhibited a more marked deviation with increasing BFS contents: from 17-32 $2 \theta$ degrees in the raw CSW to $19-382 \theta$ degrees in the activated $50 \mathrm{wt} \%$ CSW/BFS paste. As explained by Dzunuzovic et al. [30], this displacement denotes the formation of bigger amounts of amorphous binding gel due to alkali-activation reactions. These results fall in line with those previously reported by Zedan et al. [1], 
who also observed that the amorphous content in alkali-activated ceramic/BFS blends increased with the replacement percentage of the ceramic material with BFS.

A low-intensity band centered at $29.52 \theta$ degrees emerged in the spectra of the pastes that contained $30 \mathrm{wt} \%$ or $50 \mathrm{wt} \%$ BFS. This band was not distinguished in the $10 \mathrm{wt} \%$ BFS samples, where sodium carbonate thermonatrite $\left(\mathrm{T}, \mathrm{Na}_{2} \mathrm{CO}_{3} \cdot \mathrm{H}_{2} \mathrm{O}\right.$, PDF\#080448) formed instead. The band of 29-30 $2 \theta$ degrees broadened and its intensity increased with higher BFS contents. This denotes a higher amorphous gel content and is in tune with the improved compressive strength results reported in Figure 4.

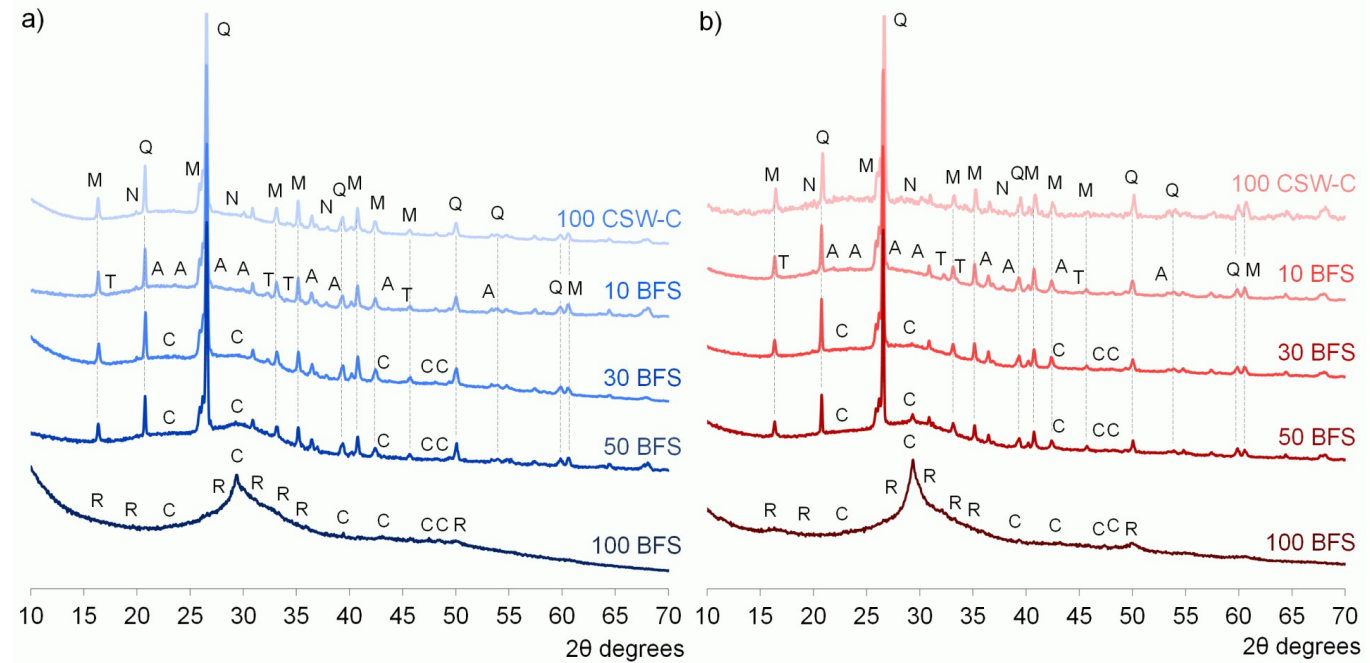

Figure 6. The powdered X-ray diffraction (XRD) spectra for the CSW / BFS blended pastes prepared with 10, 30, and $50 \mathrm{wt} \%$ BFS, cured at: (a) $20^{\circ} \mathrm{C}$ for 28 days; (b) $65{ }^{\circ} \mathrm{C}$ for 7 days. Quartz $\left(\mathrm{Q}, \mathrm{SiO}_{2}\right)$; Mullite $\left(\mathrm{M}, \mathrm{Al}_{6} \mathrm{Si}_{2} \mathrm{O}_{13}\right)$; Calcite $\left(\mathrm{C}, \mathrm{CaCO}_{3}\right)$; Anorthite $\left(\mathrm{A}, \mathrm{CaAl}_{2} \mathrm{Si}_{2} \mathrm{O}_{8}\right)$; Natron $\left(\mathrm{N}, \mathrm{Na}_{2} \mathrm{CO}_{3} \cdot 10 \mathrm{H}_{2} \mathrm{O}\right)$; Rankinite $\left(\mathrm{R}, \mathrm{Ca}_{3} \mathrm{Si}_{2} \mathrm{O}_{7}\right)$; Thermonatrite $\left(\mathrm{T}, \mathrm{Na}_{2} \mathrm{CO}_{3} \cdot \mathrm{H}_{2} \mathrm{O}\right)$.

a)

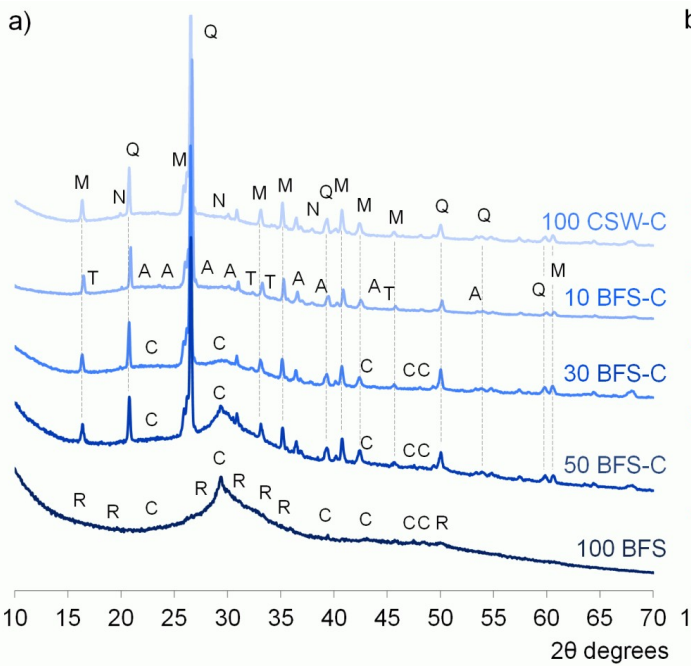

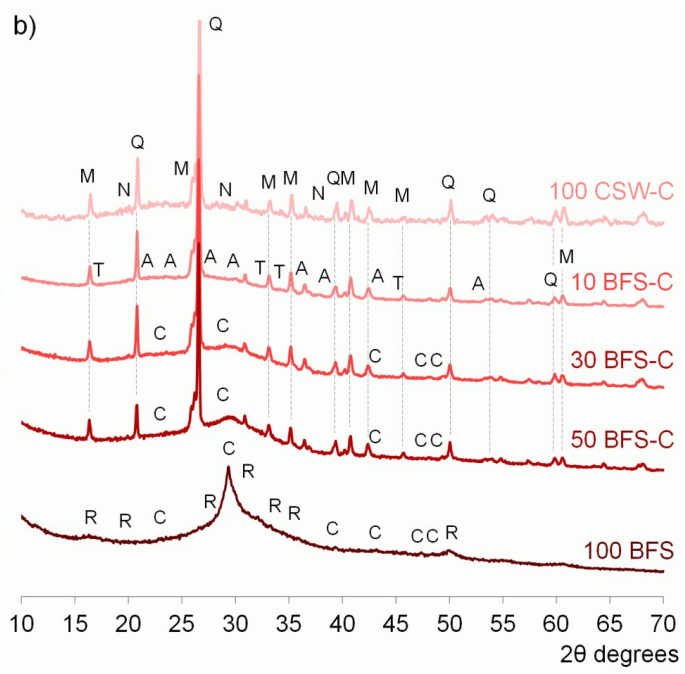

Figure 7. The XRD spectra for the CSW/BFS blended pastes that contained 4 wt $\% \mathrm{Ca}(\mathrm{OH})_{2}$ and prepared with 10, 30 and 50 wt \% BFS, cured at: (a) $20{ }^{\circ} \mathrm{C}$ for 28 days; (b) $65{ }^{\circ} \mathrm{C}$ for 7 days. Quartz $\left(\mathrm{Q}, \mathrm{SiO}_{2}\right)$; Mullite $\left(\mathrm{M}, \mathrm{Al}_{6} \mathrm{Si}_{2} \mathrm{O}_{13}\right)$; Calcite $\left(\mathrm{C}, \mathrm{CaCO}_{3}\right)$; Anorthite $\left(\mathrm{A}, \mathrm{CaAl}_{2} \mathrm{Si}_{2} \mathrm{O}_{8}\right)$; Natron $\left(\mathrm{N}, \mathrm{Na}_{2} \mathrm{CO}_{3} \cdot 10 \mathrm{H}_{2} \mathrm{O}\right)$; Rankinite $\left(\mathrm{R}, \mathrm{Ca}_{3} \mathrm{Si}_{2} \mathrm{O}_{7}\right)$; Thermonatrite $\left(\mathrm{T}, \mathrm{Na}_{2} \mathrm{CO}_{3} \cdot \mathrm{H}_{2} \mathrm{O}\right)$. 

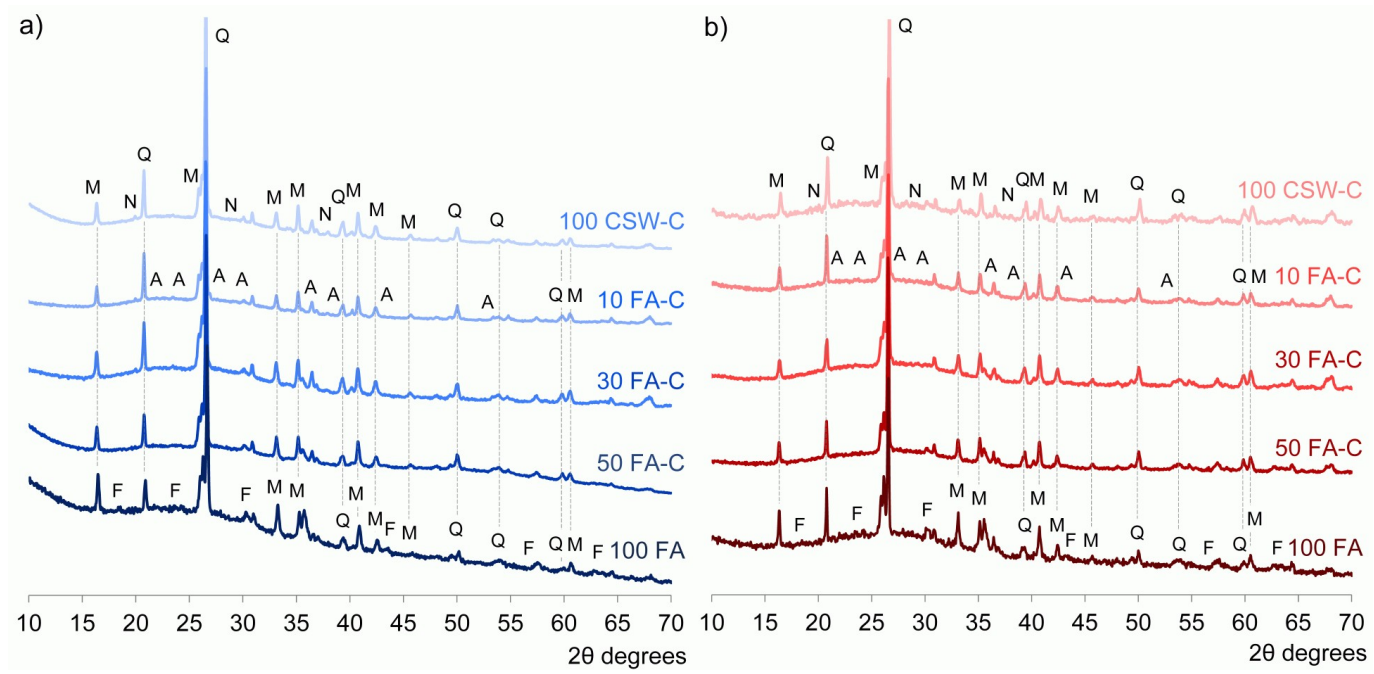

Figure 8. The XRD spectra for the CSW/FA blended pastes that contained 4 wt $\% \mathrm{Ca}(\mathrm{OH})_{2}$ and prepared with 10, 30 and 50 wt \% FA, cured at: (a) $20^{\circ} \mathrm{C}$ for 28 days; (b) $65{ }^{\circ} \mathrm{C}$ for 7 days. Quartz (Q, $\left.\mathrm{SiO}_{2}\right)$; Mullite $\left(\mathrm{M}, \mathrm{Al}_{6} \mathrm{Si}_{2} \mathrm{O}_{13}\right)$; Anorthite $\left(\mathrm{A}, \mathrm{CaAl}_{2} \mathrm{Si}_{2} \mathrm{O}_{8}\right)$; Natron $\left(\mathrm{N}, \mathrm{Na}_{2} \mathrm{CO}_{3} \cdot 10 \mathrm{H}_{2} \mathrm{O}\right)$; Maghemite $(\mathrm{F}$, $\left.\mathrm{Fe}_{2} \mathrm{O}_{3}\right)$.

\subsection{Thermogravimetric Analyses}

The results of the differential thermogravimetric analyses (DTG) for the alkali-activated CSW/FA and CSW / BFS (with and without $\mathrm{Ca}(\mathrm{OH})_{2}$ ) pastes, prepared with $0,10,30,50$, and $100 \mathrm{wt} \% \mathrm{FA}$ or BFS, are depicted in Figures 9-11. The DTG analyses of the $100 \mathrm{wt} \%$ CSW, FA, and BFS pastes were also taken as references. Figures 9 and 10 depict the DTG curves for the pastes cured at $20^{\circ} \mathrm{C}$ for 28 and 90 days, respectively, and Figure 11 presents those of the samples cured at $65{ }^{\circ} \mathrm{C}$ for 7 days. The total recorded mass loss is indicated in the figure as a percentage. All the DTG curves showed a main band within the $100-200{ }^{\circ} \mathrm{C}$ range, which was attributed to the dehydration of the gel formed during the activation reactions [31,32]. In the CSW/BFS blended pastes (both with and without $\mathrm{Ca}(\mathrm{OH})_{2}$ ), this dehydration band slightly displaced toward higher temperatures with increasing BFS contents: from $130{ }^{\circ} \mathrm{C}$ in the $100 \mathrm{wt} \% \mathrm{CSW}$ pastes to $145^{\circ} \mathrm{C}$ in the $100 \mathrm{wt} \%$ BFS pastes cured at $20{ }^{\circ} \mathrm{C}$, and from $125^{\circ} \mathrm{C}$ to $150{ }^{\circ} \mathrm{C}$ in those cured at $65^{\circ} \mathrm{C}$. Although this displacement was not observed in the $\mathrm{CSW} / \mathrm{FA}$ systems cured at $20^{\circ} \mathrm{C}$ (Figures 9 and 10), and all bands centered approximately at $130{ }^{\circ} \mathrm{C}$ (no matter what the FA content), the CSW/FA blended pastes slightly moved when cured at $65{ }^{\circ} \mathrm{C}$ compared with the $100 \mathrm{wt} \%$ activated CSW or FA (Figure 11). This shift toward higher temperatures was generally accompanied by higher mass loss values and, in agreement with Moraes et al. [32], both indicate changes in the gel formed during the activation process, which denotes the formation of phases with strongly bonded water. These results also coincide with those previously reported by Zedan et al. [1], who observed an increase in the chemically bonded water with rising BFS contents in alkali-activated ceramic waste/BFS blends (10 and $30 \mathrm{wt} \%$ replacements). The higher recorded mass loss with increasing BFS contents well agrees with the positive evolution of the compressive strength results reported in Figure 4, and also with the higher amorphous contents in the binding matrix denoted by the XRD spectra (Figures 5 and 6). Similarly, higher mass loss values were recorded in the CSW/FA blended pastes cured at $20{ }^{\circ} \mathrm{C}$ for 90 days, which also exhibited higher mass loss values compared with the $100 \mathrm{wt} \% \mathrm{FA}$ or CSW pastes. As expected [18,33], these values significantly improved when cured at $65{ }^{\circ} \mathrm{C}$, which indicates that the reactivity of these low-calcium precursors improved with thermal curing.

A new dehydration band arose on the $100 \mathrm{wt} \%$ BFS thermogravimetric curves with and without $\mathrm{Ca}(\mathrm{OH})_{2}$, which shifted from $435{ }^{\circ} \mathrm{C}$ in the pastes cured at $20{ }^{\circ} \mathrm{C}$ for 28 days, to $445{ }^{\circ} \mathrm{C}$ in those cured at $65{ }^{\circ} \mathrm{C}$ for 7 days. According to previous studies by Moraes et al. [32] and Jin et al. [34], 
this band denotes the formation of small amounts of hydrotalcite, which are commonly observed in alkali-activated $100 \mathrm{wt} \%$ BFS [2,32,34,35]. In agreement with the XRD spectra (Figures 6-8), no signals due to $\mathrm{Ca}(\mathrm{OH})_{2}$, whose bands typically arose within the $520-580{ }^{\circ} \mathrm{C}$ range [27], were distinguished in any activated pastes. This indicates that calcium participates in the activation reactions. Nor was it possible to confirm the existence of natron by the TG analyses as the signals because this sodium carbonate emerged within the $625-875{ }^{\circ} \mathrm{C}$ range [36].

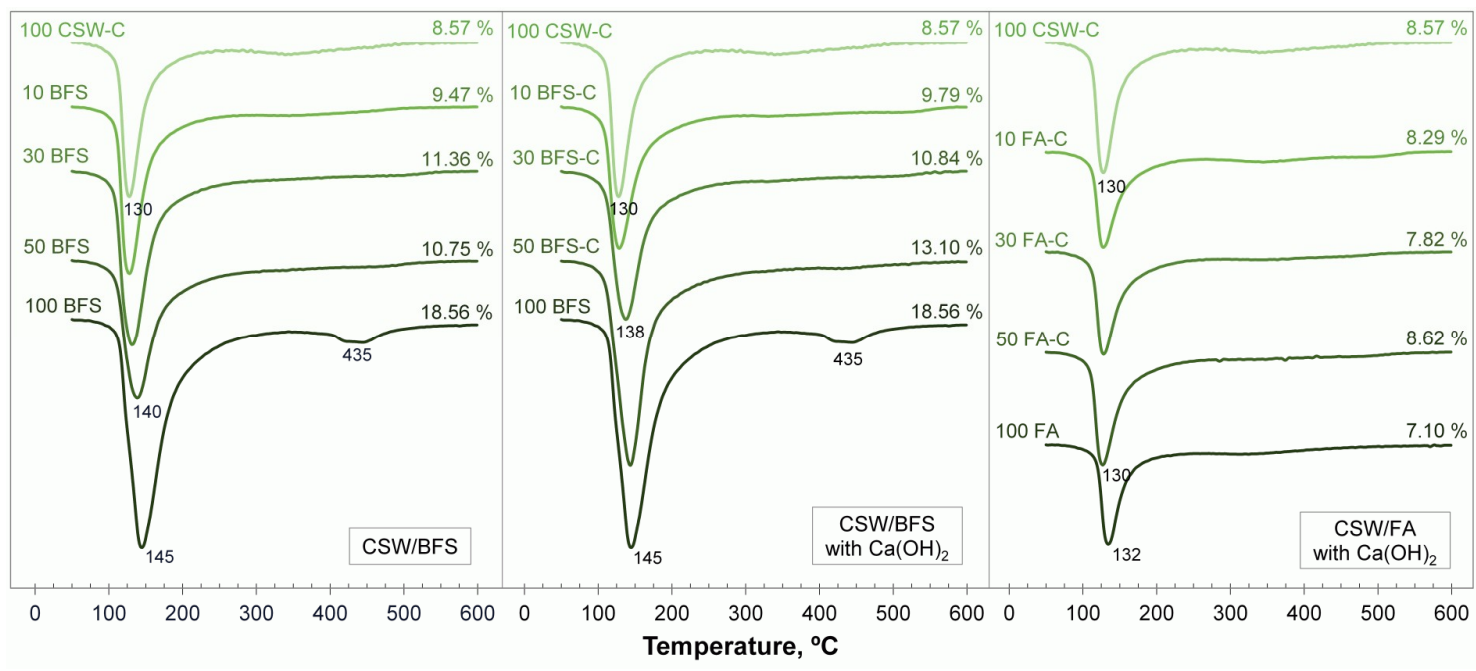

Figure 9. The differential thermogravimetric curves for the alkali-activated CSW blended pastes cured at $20^{\circ} \mathrm{C}$ for 28 days. Total mass loss is indicated as a percentage.

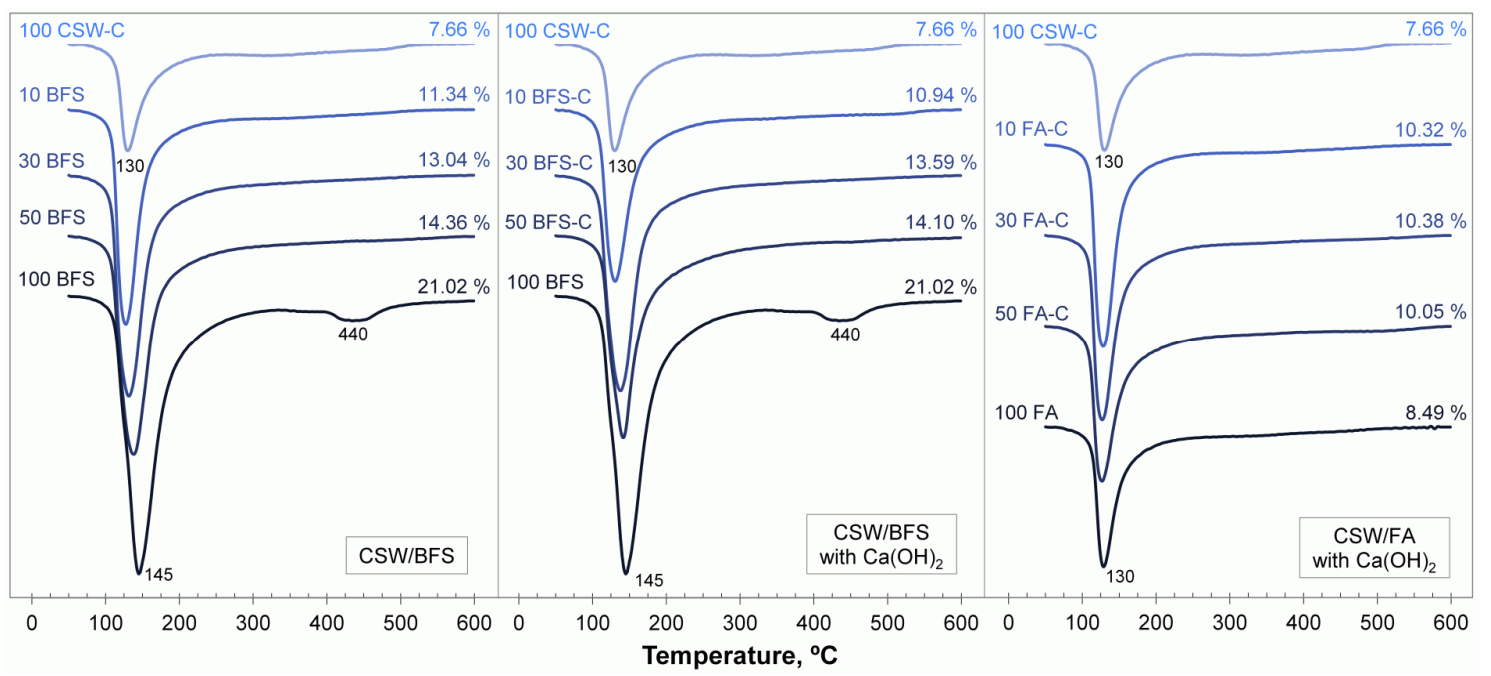

Figure 10. The differential thermogravimetric curves for the alkali-activated CSW blended pastes cured at $20^{\circ} \mathrm{C}$ for 90 days. Total mass loss is indicated as a percentage. 


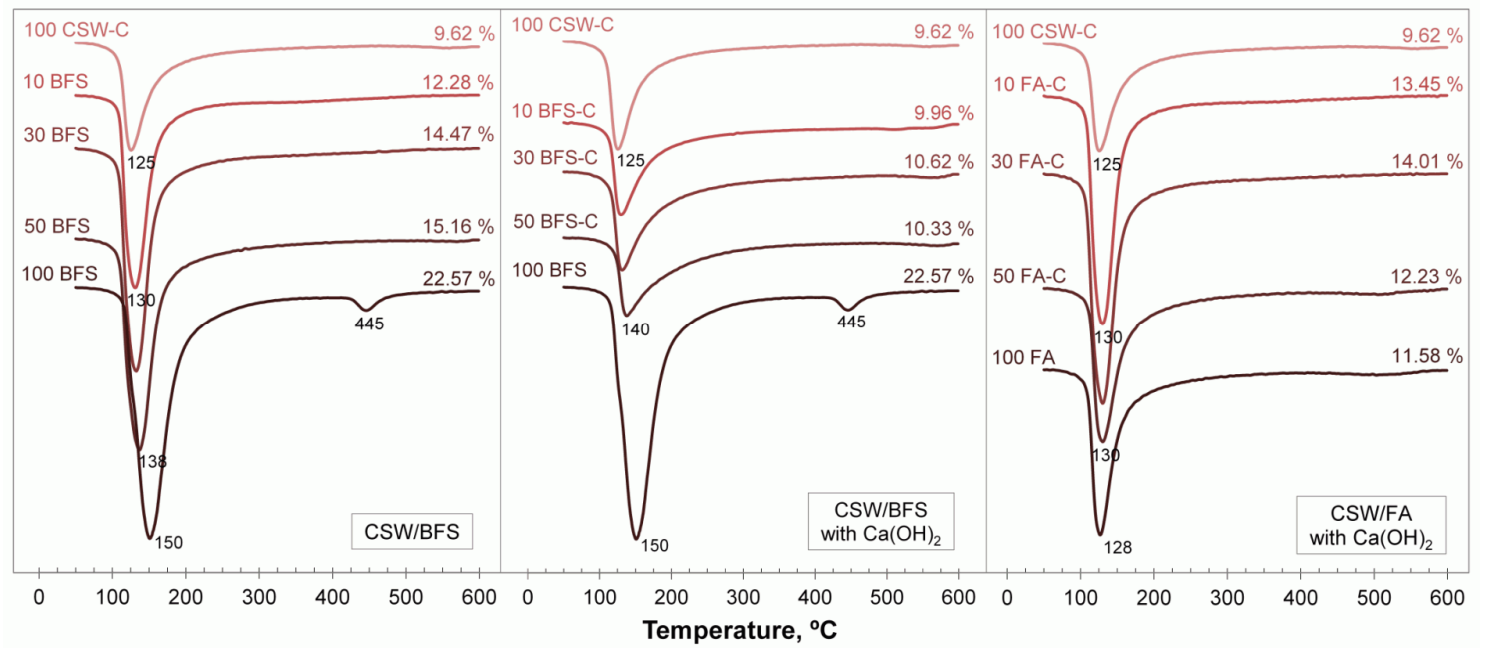

Figure 11. The differential thermogravimetric curves for the alkali-activated CSW blended pastes cured at $65{ }^{\circ} \mathrm{C}$ for 7 days. Total mass loss is indicated as a percentage.

\subsection{Field Emission Scanning Electron Microscopy (FESEM)}

The FESEM micrographs of the alkali-activated pastes prepared with $100 \mathrm{wt} \% \mathrm{CSW}$, BFS, and FA are shown in Figure 12, and those of the pastes containing $30 \mathrm{wt} \% \mathrm{BFS}$ (with and without $\mathrm{Ca}(\mathrm{OH})_{2}$ ) and $30 \mathrm{wt} \% \mathrm{FA}$ are presented in Figure 13. They were all cured at $20{ }^{\circ} \mathrm{C}$ for 28 days and at $65{ }^{\circ} \mathrm{C}$ for 7 days. The 90-day micrographs are not presented because the microstructure was similar to that observed after 28 curing days.

As observed in Figures 12 and 13, some FA particles exhibit an unaltered dense surface, while others show a partially reacted outer layer, in which the amorphous part of ash reacts and reveals its crystalline phases. As expected, as the $100 \mathrm{wt} \% \mathrm{FA}$ mortar did not set at $20^{\circ} \mathrm{C}$, the spherical FA particles observed in this paste (Figure 12) remained mainly unreacted. Conversely in agreement with the mechanical properties exhibited by the CSW/FA blended systems (Figure 4), the $30 \mathrm{wt} \%$ FA pastes showed some FA particles with a disintegrated external layer which, according to Khan et al. [37], denotes some FA reaction. These results agree with those previously reported by Rodríguez et al. [38], who associated smooth spherical particles with undissolved FA, and dendritic or rectangularly-shaped structures with crystalline low-solubility phases in partially reacted FA particles.

The 100 wt \% BFS pastes (Figure 12) had the densest microstructure, formed mainly by C-S-H/C-A-S-H gel $[19,20,35]$, and was similar no matter what the curing conditions were (65 ${ }^{\circ} \mathrm{C}$ or $20^{\circ} \mathrm{C}$ ). These results also fall in line with the compressive strength results reported in Figure 4 , and agree with those previously reported by Pan et al. [20], who also observed a denser microstructure in the $100 \mathrm{wt} \%$ BFS pastes compared with that presented by the alkali-activated $50 \mathrm{wt} \% \mathrm{FA} / \mathrm{BFS}$ blends. The $100 \mathrm{wt} \%$ CSW pastes (Figure 12) were composed mainly of unreacted or partially reacted irregularly-shaped CSW particles surrounded by the newly-formed N-A-S-H/N-(C)-A-S-H gel. Although the microstructure of the $30 \mathrm{wt} \%$ BFS pastes (with and without $\mathrm{Ca}(\mathrm{OH})_{2}$ ) was formed mainly by an amorphous-binding matrix, it was not possible to distinguish the type of gel that formed from its morphology. Small amounts of particles with a fibrous morphology were identified in the $30 \mathrm{wt} \% \mathrm{CSW} / \mathrm{BFS}$ pastes prepared with $4 \mathrm{wt} \% \mathrm{Ca}(\mathrm{OH})_{2}$, which were attributed to hydrotalcite $\left(\mathrm{Mg}_{6} \mathrm{Al}_{2}\left(\mathrm{CO}_{3}\right)_{16} \cdot 4 \mathrm{H}_{2} \mathrm{O}\right)$. Although the signals due to hydrotalcite were identified only on the DTG curves of the $100 \mathrm{wt} \%$ BFS activated pastes, and could not be clearly distinguished in the XRD spectra of the CSW / BFS blended systems, this finding was attributed to the high amorphous content in the CSW/BFS binding matrix, and to the fact that hydrotalcite probably presented poor crystallinity or small amounts formed. 


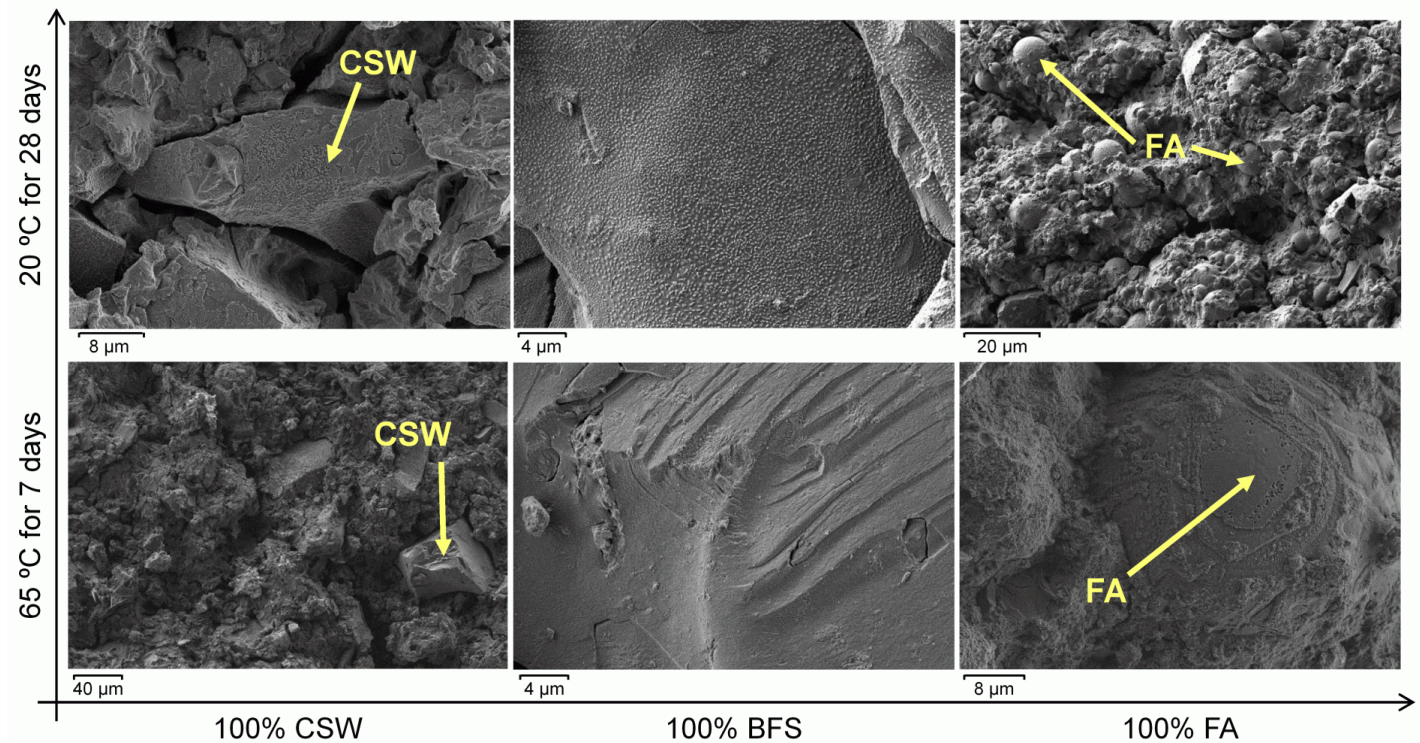

Figure 12. The field emission scanning electron images of the $100 \mathrm{wt} \%$ CSW, BFS, and FA alkali-activated pastes cured at $20^{\circ} \mathrm{C}$ for 28 days and at $65^{\circ} \mathrm{C}$ for 7 days. CSW: ceramic sanitaryware particles; FA: fly ash particles, $\mathrm{N}-(\mathrm{C})-\mathrm{A}-\mathrm{S}-\mathrm{H} / \mathrm{C}-\mathrm{S}-\mathrm{H} / \mathrm{C}-\mathrm{A}-\mathrm{S}-\mathrm{H}$ : alkali-activated gels.

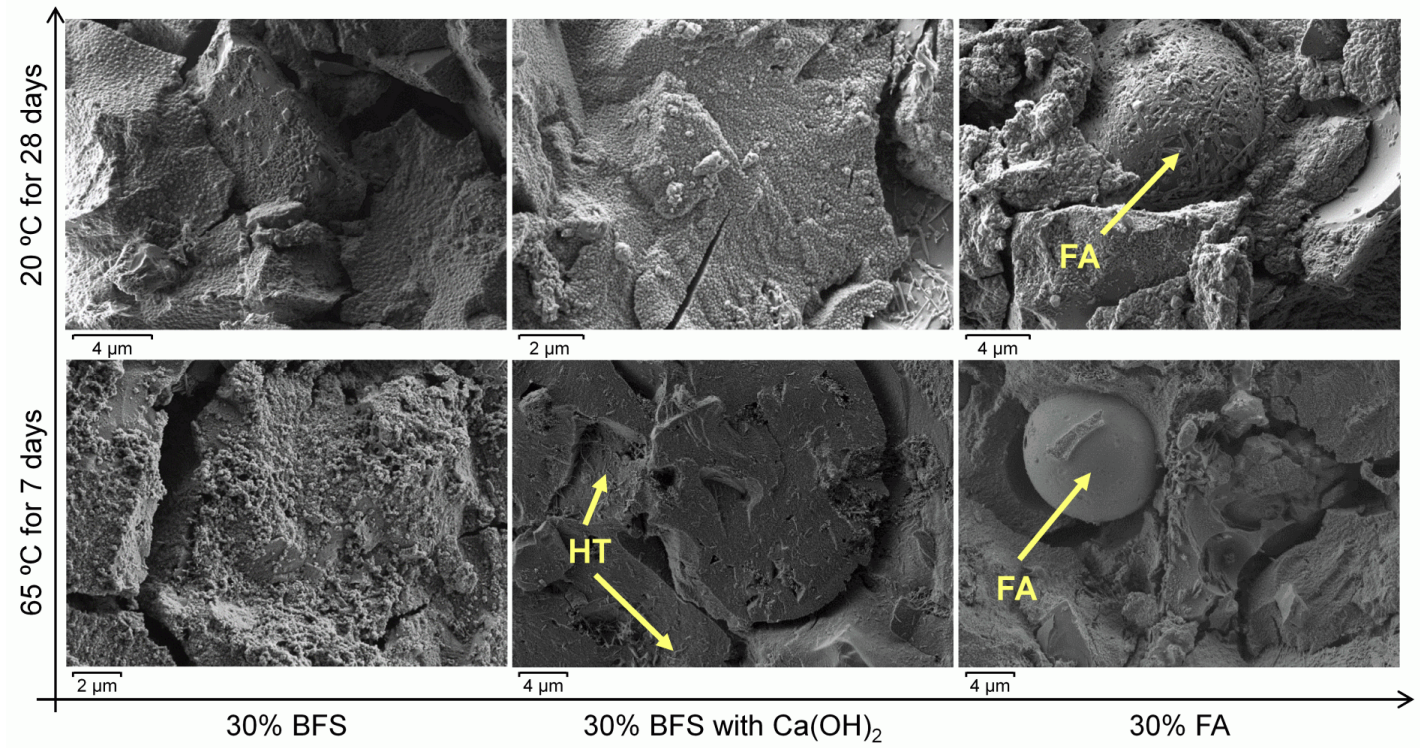

Figure 13. The field emission scanning electron images of the CSW blended pastes prepared with 30 wt $\%$ BFS (with and without $\mathrm{Ca}(\mathrm{OH})_{2}$ ) and $30 \mathrm{wt} \% \mathrm{FA}$, cured at $20{ }^{\circ} \mathrm{C}$ for 28 days and at $65{ }^{\circ} \mathrm{C}$ for 7 days. FA: fly ash particles, HT: hydrotalcite, $\mathrm{N}-(\mathrm{C})-\mathrm{A}-\mathrm{S}-\mathrm{H}$ : alkali-activated gel.

\section{Discussion}

\subsection{Strength of the CSW/BFS and CSW/FA Blended Mortars}

The partial replacement of CSW with BFS or FA allowed this ceramic waste to be activated at $20{ }^{\circ} \mathrm{C}$ and generated mortars with a wide range of mechanical properties, depending on the percentage of replacement and the curing conditions. Authors like Zedan et al. [1] or Najimi et al. [3] have attributed the better mechanical properties obtained with increasing amounts of BFS to the amorphous calcium aluminosilicates provided by BFS, which enhance the possibilities of forming hydration products. Robayo-Salazar et al. [19] have also observed how the reaction heat increases with higher BFS additions, 
which not only accelerated the process kinetics, but also favored the activation of a pozzolan at room temperature. The wide range of compressive strength results obtained falls in line with the previous study by Najimi et al. [3], who also observed a wide variation in the compressive strength results of natural pozzolan/BFS blended mortars (20 to $47 \mathrm{MPa}$ after 28 days at $20^{\circ} \mathrm{C}$ ), depending on the BFS content $(30,50$ or $70 \mathrm{wt} \%)$ and the mix proportions of the activating solutions. Robayo-Salazar et al. [19] also observed how BFS activated a natural volcanic pozzolan at room temperature, and reported improved strength values with increasing BFS contents (up to $30 \mathrm{wt} \%$, which provided $37.24 \mathrm{MPa}$ in the mortars cured at $20^{\circ} \mathrm{C}$ for 28 days). Similarly, Pan et al. [20] also found that adding BFS allowed FA to activate at room temperature, and these authors reported strength values of $29 \mathrm{MPa}$ in the $50 \mathrm{wt} \%$ FA/BFS mortars cured at room temperature for 28 days. In the study by Zedan et al. [10], the strength of alkali-activated ceramic waste mortars cured for 28 days also improved by going from $10 \mathrm{MPa}$ to almost 40 MPa when blended with $30 \mathrm{wt} \%$ BFS.

The obtained results significantly extend the field of applications of alkali-activated CSW blended cements. However, FA and BFS are valuable by-products that can be easily reused in different construction applications, and are employed mainly as pozzolanic admixtures in Portland cement $[5,6,8,39,40]$. Although 13.6 million tons of steel were produced in Spain in 2016 (16th highest steel production country), only 4.6 MT were manufactured in blast furnaces (33.9\%), and the remaining $66.1 \%$ (9.0 MT) was produced in electric furnaces [9]. Nowadays, Spanish iron blast furnaces operate only in Gijón (north Spain), and the amount of BFS consumed by Spanish cement companies is larger than that produced [8], which implies that some BFS is imported. Consequently, it is recommended to use as small as possible BFS or FA amounts, depending on the specific use of the binder. In this sense, the CSW mortars containing 20-30 wt \% BFS or FA exhibited compressive strength values within the 22.1-37.6 MPa range after 7 curing days at $65^{\circ} \mathrm{C}$, and 6.9-21.1 MPa after 28 days at $20^{\circ} \mathrm{C}$. These binders can be used mainly in low-strength applications (e.g., nonstructural concrete or blocks) or prefabricated systems (where temperature can be easily applied to cure samples). For high-strength applications, the C-BFS40 and C-BFS50 systems can be selected with strength values that come close to 30 and $40 \mathrm{MPa}$ after 28 curing days at $20{ }^{\circ} \mathrm{C}$. However, as these mortars use large amounts of BFS, CSW can alternatively be blended with CAC, PC [24] or fluid catalytic cracking waste (FCC, an industrial by-product) [26] when high strength binders or shorter curing periods are required. Compressive strength values of $66.3 \mathrm{MPa}$ and 78.6 MPa have been reported in alkali-activated CSW mortars blended with $15 \mathrm{wt} \% \mathrm{PC}$ or $20 \mathrm{wt} \% \mathrm{CAC}$, respectively (cured at $65{ }^{\circ} \mathrm{C}$ for 7 days). However, as highlighted by the authors [24], CAC or PC production implies the use of natural resources and requires vast amounts of energy. Thus, an alternative with a higher added value would be to blend CSW with FCC [26], which gave compressive strength results that came close to $40 \mathrm{MPa}$ in the mortars cured at $20^{\circ} \mathrm{C}$ for 28 days (made with $30 \mathrm{wt} \%$ FCC and the same mix proportions as those used herein).

\subsection{Types of Gels Formed}

As Ranjbar et al. described [7], during the synthesis of geopolymers, the aluminate and silicate monomers released from dissolved precursors form dissolved species. They cross-link to form oligomers, which arrange to form an aluminosilicate gel. Si and $\mathrm{Al}$ are tetrahedrally bonded with oxygen so that the basic monomer units $\left(\mathrm{AlO}_{4}{ }^{-}\right)$are negatively charged [41]. Although these charges are balanced by the alkali cations in the system $\left(\mathrm{Na}^{+}\right)$, they may also be balanced by $\mathrm{Ca}^{2+}$ in the presence of reactive calcium. Thus, in the presence of calcium, different types of gels may co-exist in the binding matrix. Ismail et al. [29], who investigated the effect of FA on BFS blended systems, observed that the structure of silicate-activated slag pastes was formed mainly by a C-A-S-H gel, activated fly ash was composed chiefly by a N-A-S-H gel, and both gels co-existed in slag-fly ash blended binders. Marjanovic et al. [2] observed that the co-existence of both N-A-S-H and C-A-S-H gels strongly depends on both the blend proportions and the activator concentration. Previous studies into the alkali-activation of blended precursors $[2,29,32,35]$ suggest that $\mathrm{N}-\mathrm{A}-\mathrm{S}-\mathrm{H}$ or low-calcium $\mathrm{N}-(\mathrm{C})-\mathrm{A}-\mathrm{S}-\mathrm{H}$ gels most probably formed in the $100 \mathrm{wt} \% \mathrm{CSW}$ or CSW/FA blended systems, and that 
$\mathrm{N}-(\mathrm{C})-\mathrm{A}-\mathrm{S}-\mathrm{H}$ gels presumably arose in the CSW / BFS binders, with bigger amounts of calcium and closer to $\mathrm{C}-\mathrm{S}-\mathrm{H} / \mathrm{C}-\mathrm{A}-\mathrm{S}-\mathrm{H}$ with increasing slag contents.

The signal at $29.52 \theta$ degrees in the diffraction pattern of alkali-activated slag has been attributed by authors like Burciaga-Díaz et al. [35] and Pan el al. [20] to the formation of a poorly crystalline calcium silicate hydrate C-S-H with partial replacement of Si with $\mathrm{Al}(\mathrm{C}-\mathrm{A}-\mathrm{S}-\mathrm{H})$. In the study by Pan et al. [20], a C-S-H binding gel was formed mainly in alkali-activated $100 \mathrm{wt} \% \mathrm{BFS}$, and the partial replacement of FA with BFS gave a combination of N-A-S-H and C-A-S-H gels. As observed by these authors [20], as the C-S-H gel formed in pore solutions with high $\mathrm{SiO}_{2}$ concentrations, it presented a lower $\mathrm{CaO} / \mathrm{SiO}_{2}$ ratio compared with the C-S-H gel that typically forms in PC. No signals within the 29-30 $2 \theta$ degrees range arose in the spectra of the CSW/FA systems studied herein. Given the low $\mathrm{CaO}$ content in the original CSW and FA (lower than $4 \mathrm{wt} \%$; see Table 4), a N-A-S-H or a N-(C)-A-S-H gel was expected to form, with calcium provided mainly by the $4 \mathrm{wt} \% \mathrm{Ca}(\mathrm{OH})_{2}$ addition. The XRD results agree with those obtained by DTG as the main dehydration band slightly displaced toward higher temperatures with increasing BFS contents, and hardly moved in the CSW/FA blended systems cured at $20^{\circ} \mathrm{C}$, but exhibited a minor displacement when these CSW/FA blended pastes were cured at $65^{\circ} \mathrm{C}$. As observed by Ismail et al. [29] and Djobo et al. [41], these higher dehydration temperatures denote a modification in the gel structure, with free water more tightly bound or with smaller pores. Thus, in the CSW/BFS blended cements, the slightly higher dehydration temperatures would be attributed to the incorporation of calcium into the binding gel, while they would be explained by the formation of a more cross-linked structure with smaller pores in the CSW/FA pastes cured at $65{ }^{\circ} \mathrm{C}$.

\subsection{Role of Calcium in the Kinetics of the Process}

In agreement with the results reported in $[24,26]$, where no $\mathrm{Ca}(\mathrm{OH})_{2}$ was identified after the activation of CSW [24] or CSW/FCC blends [26], no signals due to $\mathrm{Ca}(\mathrm{OH})_{2}$ arose in the XRD spectra or DTG curves of the alkali-activated CSW blended pastes. This indicates that $\mathrm{Ca}(\mathrm{OH})_{2}$ was consumed during the alkali-activation reactions. In line with the obtained results, Chen et al. [4] observed that adding calcium to metakaolin geopolymers enhanced the rate and extent of MK dissolution. The higher dissolution rates of the precursor increased the $\mathrm{Al}$ concentration in the solution as $\mathrm{Al}$ tends to dissolve faster than $\mathrm{Si}$ [4]. As explained by Ranjbar et al. [7], the bigger amounts of $\mathrm{Al}(\mathrm{OH})_{4}{ }^{-}$species available for condensation at early ages improve the condensation rate between silicate and aluminate species, rather than only between silicate species. Since the condensation between silicate species is slower than that between silicate and aluminate species [42], this accelerates the reaction kinetics, and originates higher initial strength and shorter setting times [4,7]. Briefly, the higher dissolution rates promoted by adding $\mathrm{Ca}(\mathrm{OH})_{2}$ increases the $\mathrm{Al}$ concentration in the solution, which strongly influences the setting time of the developed mortars due to accelerated gel formation. However as pointed out by Silva et al. [42], the Si present in the alkali-activated systems determines the type of silica-aluminate structures that form, and is responsible for a higher later strength development.

\subsection{Future Research}

The further research conducted (Sections 2.4 and 3.2.1) confirmed that BFS mainly reacted with the activating solution in the $50 \mathrm{wt} \% \mathrm{BFS}$ blended mortars prepared with $4 \mathrm{wt} \% \mathrm{Ca}(\mathrm{OH})_{2}$. This resulted in an excess of alkalis for the amount of BFS in the blended cements, which consequently diminished the mechanical properties of these mortars. As observed by Silva et al. [42], the properties of an alkali-activated binder may significantly be improved by making minor changes in the $\mathrm{Si}$ and $\mathrm{Al}$ concentrations available during synthesis. Hence the obtained results open up a new interesting research line to be explored in order to optimize the mix proportions in the activating solutions, depending on the amount of BFS or FA in the CSW blended systems. 


\section{Conclusions}

The present research investigated the effect of partially replacing CSW with BFS or FA, together with the influence of $\mathrm{Ca}(\mathrm{OH})_{2}$ additions, on the microstructure and compressive strength of alkali-activated CSW blended cements. Based on the results, the following conclusions can be drawn:

- $\quad$ The compressive strength of the $100 \mathrm{wt} \%$ CSW mortars improved with BFS or FA content. The best results were provided by the CSW/BFS blended systems with the $\mathrm{Ca}(\mathrm{OH})_{2}$ addition, which reached almost $55 \mathrm{MPa}$ after 90 curing days at $20^{\circ} \mathrm{C}$ or 7 days at $65^{\circ} \mathrm{C}$.

- $\quad$ The BFS mortars presented better strength results than FA, especially when cured at $20^{\circ} \mathrm{C}$.

- BFS mainly reacted with the activating solution in the CSW / BFS blended cements, which led to a significant loss of strength compared to the $100 \mathrm{wt} \%$ BFS sample. This was attributed to excess reagents for the diluted amount of BFS in the system.

- Although 4 wt \% $\mathrm{Ca}(\mathrm{OH})_{2}$ was consumed mainly by BFS in the CSW/BFS blended systems, the $8 \mathrm{wt} \%$ additions promoted the reactivity of CSW, which also conferred the binder strength.

- No significant new crystalline phases were identified in the CSW blended cements, and $\mathrm{Ca}(\mathrm{OH})_{2}$ reacted during the alkali-activation process.

- Although it was not possible to clearly differentiate the different types of gel that formed, $\mathrm{N}-\mathrm{A}-\mathrm{S}-\mathrm{H}$ and low-calcium N-(C)-A-S-H gels most probably formed in the CSW/FA blended systems, and a combination of $\mathrm{N}-(\mathrm{C})-\mathrm{A}-\mathrm{S}-\mathrm{H} / \mathrm{C}-\mathrm{S}-\mathrm{H} / \mathrm{C}-\mathrm{A}-\mathrm{S}-\mathrm{H}$ gels formed in the CSW /BFS binary cements.

The combination of CSW with BFS or FA significantly broadens the possibilities of reusing and valorizing a ceramic waste generated in large quantities worldwide as a precursor in alkali-activated blended cements. The new low- $\mathrm{CO}_{2}$ binders developed are a potential alternative to Portland cement to help preserve the environment.

Author Contributions: J.M.M., M.V.B. and J.P. conceived and designed the experiments; J.C. and L.S. ran the experiments; L.S., L.R. and J.C. analyzed the data; L.R. and L.S. wrote the paper, which was reviewed by all the authors.

Funding: This research received financial support from the Spanish Ministry of Science and Innovation through Project APLIGEO BIA2015-70107-R and FEDER funds.

Acknowledgments: Spanish Ministry of Science and Innovation through Project APLIGEO BIA2015-70107-R and FEDER. The authors would also like to thank the companies Ideal Standard, Balalva S.L. and Cementval S.L., for respectively supplying the raw CSW, FA and BFS materials. Thanks also go to the Electron Microscopy Service of the Universitat Politècnica de València.

Conflicts of Interest: The authors declare no conflict of interest.

\section{References}

1. Zedan, S.R.; Mohamed, M.R.; Ahmed, D.A.; Mohammed, A.H. Alkali activated ceramic waste with or without two different calcium sources. Adv. Mater. Res. 2015, 4, 133-144. [CrossRef]

2. Marjanović, N.; Komljenović, M.; Baščarević, Z.; Nikolić, V.; Petrović, R. Physical-mechanical and microstructural properties of alkali-activated fly ash-blast furnace slag blends. Ceram. Int. 2015, 41, 1421-1435. [CrossRef]

3. Najimi, M.; Ghafoori, N.; Sharbaf, M. Alkali-activated natural pozzolan/slag mortars: A parametric study. Constr. Build. Mater. 2018, 164, 625-643. [CrossRef]

4. Chen, X.; Sutrisno, A.; Struble, L.J. Effects of calcium on setting mechanism of metakaolin-based geopolymer. J. Am. Ceram. Soc. 2018, 101, 957-968. [CrossRef]

5. CEDEX, Center for Studies and Experimentation of Public Works-Ministerio de Fomento. Gobierno de España: Catálogo de Residuos. Ficha Técnica Cenizas Volantes De Carbón Y Cenizas De Hogar O Escorias. 2011. Available online: http://www.cedexmateriales.es/catalogo-de-residuos/24/diciembre2011/ (accessed on 4 August 2018). (In Spanish) 
6. Toniolo, N.; Boccaccini, A.R. Fly ash-based geopolymers containing added silicate waste. A review. Ceram. Int. 2017, 43, 14545-14551. [CrossRef]

7. Ranjbar, N.; Kuenzel, C. Cenospheres: A review. Fuel 2017, 207, 1-12. [CrossRef]

8. CEDEX, Center for Studies and Experimentation of Public Works-Ministerio de Fomento. Gobierno de España: Catálogo de Residuos. Ficha Técnica Escorias De Horno Alto. 2011. Available online: http: / / www.cedexmateriales.es/catalogo-de-residuos/39/escorias-de-horno-alto/ (accessed on 4 August 2018). (In Spanish)

9. World Steel Association, World Steel in Figures 2017. Available online: https://www.worldsteel.org (accessed on 4 August 2018).

10. US Geological Survey, Mineral Resources Program, Iron and Steel Slag. Available online: https://minerals. usgs.gov/minerals/pubs/commodity/iron_\&_steel_slag/mcs-2017-fesla.pdf (accessed on 4 August 2018).

11. Pacheco-Torgal, F.; Castro-Gomes, J.; Jalali, S. Alkali-activated binders: A review. Part 2. About materials and binders manufacture. Constr. Build. Mater. 2008, 22, 1315-1322. [CrossRef]

12. Mehta, A.; Siddique, R. An overview of geopolymers derived from industrial by-products. Constr. Build. Mater. 2016, 127, 183-198. [CrossRef]

13. Mellado, A.; Catalán, C.; Bouzón, N.; Borrachero, M.V.; Monzó, J.; Payá, J. Carbon footprint of geopolymeric mortar: Study of the contribution of the alkaline activating solution and assessment of alternative route. RSC Adv. 2014, 4, 23846-23852. [CrossRef]

14. Mohammed, S. Processing, effect and reactivity assessment of artificial pozzolans obtained from clays and clay wastes: A review. Constr. Build. Mater. 2017, 140, 10-19. [CrossRef]

15. Halicka, A.; Ogrodnik, P.; Zegardlo, B. Using ceramic sanitary ware waste as concrete aggregate. Constr. Build. Mater. 2013, 48, 295-305. [CrossRef]

16. Bernasconi, A.; Diella, V.; Pagani, A.; Pavese, A.; Francescon, F.; Young, K.; Stuart, J.; Tunnicliffe, L. The role of firing temperature, firing time and quartz grain size on phase-formation, thermal dilatation and water absorption in sanitary-ware vitreous bodies. J. Eur. Ceram. Soc. 2011, 31, 1353-1360. [CrossRef]

17. Baraldi, L. World sanitaryware production and exports. Ceram. World Rev. 2015, 114, 56-65.

18. Reig, L.; Borrachero, M.V.; Monzó, J.; Savastano, H.; Tashima, M.M.; Payá, J. Use of ceramic sanitaryware as an alternative for the development of new sustainable binders. Key Eng. Mater. 2016, 668, 172-180. [CrossRef]

19. Robayo-Salazar, R.A.; de Gutiérrez, M.; Puertas, F. Study of synergy between a natural volcanic pozzolan and a granulated blast furnace slag in the production of geopolymeric pastes and mortars. Constr. Build. Mater. 2017, 157, 151-160. [CrossRef]

20. Pan, Z.; Tao, Z.; Cao, Y.F.; Wuhrer, R.; Murphy, T. Compressive strength and microstructure of alkali-activated fly ash/slag binders at high temperature. Cem. Concr. Compos. 2018, 86, 9-18. [CrossRef]

21. Tashima, M.M.; Reig, L.; Santini, M.A.; B Moraes, J.C.; Akasaki, J.L.; Payá, J.; Borrachero, M.V.; Soriano, L. Compressive Strength and Microstructure of Alkali-Activated Blast Furnace Slag/Sewage Sludge Ash (GGBS/SSA) Blends Cured at Room Temperature. Waste Biomass Valorization 2017, 8, 1441-1451. [CrossRef]

22. Perná, I.; Hanzlíček, T. The setting time of a clay-slag geopolymer matrix: The influence of blast-furnace-slag addition and the mixing method. J. Clean. Prod. 2016, 112, 1150-1155. [CrossRef]

23. El-Naggar, M.R.; Amin, M. Impact of alkali cations on properties of metakaolin and metakaolin/slag geopolymers: Microstructures in relation to sorption of 134Cs radionuclide. J. Hazard. Mater. 2018, 344, 913-924. [CrossRef] [PubMed]

24. Reig, L.; Soriano, L.; Tashima, M.M.; Borrachero, M.V.; Monzó, J.; Payá, J. Influence of calcium additions on the compressive strength and microstructure of alkali-activated ceramic sanitary-ware. J. Am. Ceram. Soc. 2018, 101, 3094-3104. [CrossRef]

25. García-Lodeiro, I.; Fernández-Jiménez, A.; Palomo, A. Variation in hybrid cements over time. Alkaline activation of fly ash-portland cement blends. Cem. Concr. Res. 2013, 52, 112-122. [CrossRef]

26. Cosa, J.; Soriano, L.; Borrachero, M.; Reig, L.; Payá, J.; Monzó, J. Influence of Addition of Fluid Catalytic Cracking Residue (FCC) and the $\mathrm{SiO}_{2}$ Concentration in Alkali-Activated Ceramic Sanitary-Ware (CSW) Binders. Minerals 2018, 8, 123. [CrossRef]

27. Reig, L.; Soriano, L.; Borrachero, M.V.; Monzó, J.; Payá, J. Influence of the activator concentration and calcium hydroxide addition on the properties of alkali-activated porcelain stoneware. Const. Build. Mater. 2014, 63, 214-222. [CrossRef] 
28. Temuujin, J.; Williams, R.P.; van Riessen, A. Effect of mechanical activation of fly ash on the properties of geopolymer cured at ambient temperature. J. Mater. Process. Technol. 2009, 209, 5276-5280. [CrossRef]

29. Ismail, I.; Bernal, S.A.; Provis, J.L.; San Nicolas, R.; Hamdan, S.; Van Deventer, J.S.J. Modification of phase evolution in alkali-activated blast furnace slag by the incorporation of fly ash. Cem. Concr. Compos. 2014, 45, 125-135. [CrossRef]

30. Džunuzović, N.; Komljenović, M.; Nikolić, V.; Ivanović, T. External sulfate attack on alkali-activated fly ash-blast furnace slag composite. Constr. Build. Mater. 2017, 157, 737-747. [CrossRef]

31. Fernández-Jiménez, A.; Palomo, A.; Sobrados, I.; Sanz, J. The role played by the reactive alumina content in the alkaline activation of fly ashes. Microporous Mesoporous Mater. 2006, 91, 111-119. [CrossRef]

32. De Moraes, J.C.B.; Tashima, M.M.; Melges, J.L.P.; Akasaki, J.L.; Monzó, J.; Borrachero, M.V.; Soriano, L.; Payá, J. Optimum Use of Sugar Cane Straw Ash in Alkali-Activated Binders Based on Blast Furnace Slag. J. Mater. Civ. Eng. 2018, 30, 4018084. [CrossRef]

33. Rashad, A.M. A comprehensive overview about the influence of different admixtures and additives on the properties of alkali-activated fly ash. Mater. Des. 2014, 53, 1005-1025. [CrossRef]

34. Jin, F.; Gu, K.; Al-Tabbaa, A. Strength and hydration properties of reactive MgO-activated ground granulated blastfurnace slag paste. Cem. Concr. Compos. 2015, 57, 8-16. [CrossRef]

35. Burciaga-Díaz, O.; Escalante-García, J.I. Comparative performance of alkali activated slag/metakaolin cement pastes exposed to high temperatures. Cem. Concr. Compos. 2017, 84, 157-166. [CrossRef]

36. Hidalgo, A.; García, J.L.; Alonso, M.C.; Fernández, L.; Andrade, C. Microstructure development in mixes of calcium aluminate cement with silica fume or fly ash. J. Therm. Anal. Calorim. 2009, 96, 335-345. [CrossRef]

37. Khan, M.Z.N.; Shaikh, F.; uddin Ahmed Shaikh, F.; Hao, Y.; Hao, H. Synthesis of high strength ambient cured geopolymer composite by using low calcium fly ash. Constr. Build. Mater. 2016, 125, 809-820. [CrossRef]

38. Rodríguez, E.D.; Bernal, S.A.; Provis, J.L.; Paya, J.; Monzo, J.M.; Borrachero, M.V. Effect of nanosilica-based activators on the performance of an alkali-activated fly ash binder. Cem. Concr. Compos. 2013, 35, 1-11. [CrossRef]

39. Dwivedi, A.; Jain, M.K. Fly ash-waste management and overview: A Review. Recent Res. Sci. Technol. 2014, 6, 30-35.

40. Ministry of Public Works. RC-16. Instrucción para la Recepción de Cementos (CementReceptionInstruction); Ministry of Public Works: Madrid, Spain, 2016.

41. Djobo, J.N.Y.; Tchakouté, H.K.; Ranjbar, N.; Elimbi, A.; Tchadjié, L.N.; Njopwouo, D. Gel Composition and Strength Properties of Alkali-Activated Oyster Shell-Volcanic Ash: Effect of Synthesis Conditions. J. Am. Ceram. Soc. 2016, 99, 3159-3166. [CrossRef]

42. Silva, P.D.; Sagoe-Crenstil, K.; Sirivivatnanon, V. Kinetics of geopolymerization: $\operatorname{Role}$ of $\mathrm{Al}_{2} \mathrm{O}_{3}$ and $\mathrm{SiO}_{2}$. Cem. Concr. Res. 2007, 37, 512-518. [CrossRef]

(C) 2018 by the authors. Licensee MDPI, Basel, Switzerland. This article is an open access article distributed under the terms and conditions of the Creative Commons Attribution (CC BY) license (http://creativecommons.org/licenses/by/4.0/). 